\title{
O enquadramento das Missões de Paz (PKO) nas teorias da guerra e de polícia
}

\section{DOMÍCIO PROENÇA JÚNIOR*}

\section{Introdução}

Then it's Tommy this, an’ Tommy that, an' “Tommy 'ow's yer soul?” But it's “Thin red line of 'eroes” when the drums begin to roll-

The drums begin to roll, my boys, the drums begin to roll, O it's “ Thin red line of 'eroes,” when the drums begin to roll.

For it's Tommy this, an’ Tommy that, an' "Chuck 'im out, the brute!”

But it's "Saviour of 'is country" when the guns begin to shoot; An' it's Tommy this, an' Tommy that, an' anything you please; An’ Tommy ain’t a bloomin’ fool - you bet that Tommy sees!

“Tommy”, Rudyard Kipling, 1892

A clareza original do que sejam as Operações de Manutenção, ou Missões de Paz (Peacekeeping Operations - PKO), já não existe, se é que algum dia ela de fato existiu ${ }^{1}$. As PKO em suas várias denominações e variantes qualificadas se tornaram, crescentemente, o que quer que as Forças de Paz sejam chamadas a fazer, apesar de várias tentativas de Secretários-Gerais da ONU, funcionários dos mais diversos organismos e de estudiosos para fixar o que se supõe deva ser entendido pelos diversos termos usados para descrevê-las² .

Há diversos entendimentos do que sejam PKO. Esses entendimentos agregam em todos os casos expectativas tanto políticas quanto táticas. Buscam estabelecer, ainda, as bases dos procedimentos e o conteúdo das regras sob as quais as PKO deveriam ter lugar. Apesar disso, esses entendimentos divergem quanto à extensão, mandato e expectativas das $\mathrm{PKO}^{3}$.

Isso é inteiramente insatisfatório. Deixa as considerações políticas e táticas que têm que orientar e constranger as PKO abertas, como arranjos ad hoc ou, 
pior, expostas a enganos substantivos sobre seu propósito, natureza, possibilidades e métodos.

Não é surpresa que tal estado de coisas seja freqüentemente apontado como a fonte da ineficácia de PKO, seja em termos do resultado esperado, seja em termos dos métodos empregados ${ }^{4}$. Além disso, essa ausência de clareza engendra ainda a possibilidade de que se tome qualquer caso como exemplar ou como particularmente significativo, conduzindo a interpretações divergentes do valor ou dos vários tipos de PKO. ${ }^{5}$

Esse artigo oferece algumas considerações sobre o estatuto teórico de PKO. É resultado parcial de um programa de pesquisa em comum entre o Grupo de Estudos Estratégicos da Universidade Federal do Rio de Janeiro e o Centro de Estudos das Américas da Universidade Cândido Mendes. Trata das conseqüências mais proeminentes desse trabalho para o entendimento da natureza das PKO, com implicações para seu planejamento, execução e avaliação.

Com essa perspectiva, trata-se de texto aberto e francamente argumentativo, uma composição exploratória com um foco estreito. Não é minha intenção dar conta de todas as perguntas, enfocar todos os assuntos ou revisar todos os casos de todos os pontos de vista. Ao mesmo tempo, evitei deliberadamente dobrar-me diante de práticas estabelecidas, buscando os benefícios de uma aproximação direta a estruturas teóricas consolidadas na esperança de achar uso para os resultados assim obtidos.

Não é minha intenção, com essa postura, insinuar que outras abordagens não tenham relevância; pelo contrário, reconheço explícita e prontamente meu uso de muito de seu acervo e minha interação com elas no processo do estudo. É que simplesmente reconheço que seriam obstáculos ao que tenho a dizer nesse momento. Como resultado, dou uma visão sumária de meus resultados atuais, esforçando-me para não considerar o conteúdo destas outras abordagens enquanto exponho o que me parece ser o cerne mesmo da questão de $\mathrm{PKO}^{6}$.

O artigo começa com uma preliminar inevitável, que busca compartilhar um conjunto de entendimentos de partida essenciais sobre força e violência, uso da força, guerra e paz. A partir daí, reconhece-se a pertinência de distinguir as trajetórias políticas, doutrinárias, e conceituais do que poderia ser denominado de “estudos de PKO”, como pano de fundo necessário para a apresentação da oportunidade e pertinência de uma aproximação teórica.

Dirige-se, então, para o enquadramento de PKO como objeto da teoria de guerra $^{7}$. Adianta a conclusão segundo a qual as PKO são uma forma de guerra de coalizão. Essa conclusão conduz a outras considerações. Segue a essas o enquadramento de PKO como objeto da teoria de polícia ${ }^{8}$. O artigo conclui que as PKO envolvem responsabilidades de policiamento multicultural de um tipo particular, um "policiamento comunitário da alteridade" e tece, ademais, algumas considerações a tal respeito. O artigo termina com observações sobre a utilidade desses enquadramentos. 


\section{Preliminares}

Nessas preliminares, busco clarificar um determinado conjunto de entendimentos de partida, reconheço as trajetórias políticas, doutrinárias, e conceituais de estudos de PKO e discuto o valor de uma aproximação teórica. Isso parece essencial para permitir que PKO possa ser tomado enquanto objeto, sucessivamente, da teoria de guerra e da teoria de polícia.

\subsection{Força e violência, uso de força, guerra e paz}

Não será possível ir muito longe em qualquer tentativa de tratar o tema das Operações de Manutenção da Paz (Peacekeeping Operations - PKO) sem se construir um entendimento mínimo sobre alguns fundamentos. É imediatamente necessário trazer adiante uma distinção essencial entre força e violência num contexto social; clarificar o que é entendido como uso de força em seus aspectos concretos e potenciais, e o que se quer dizer com o termo guerra e, como resultado, com o termo paz.

\subsubsection{Força e violência}

Para os fins desse artigo, tanto força quanto violência implicam o uso de ação ou constrangimento físico. Em termos mais gerais, uma transmissão orientada de energia: por exemplo, forçando uma porta emperrada ou imobilizando uma pessoa; indo mais adiante, represando um rio ou pondo minas terrestres num trecho de terreno.

Em condições sociais, porém, a escolha do termo violência insinua que tal uso se dá num contexto carente de sanção de autoridade competente (ilegal ou ilegítimo); ou de forma descontrolada (imprópria ou irracional). Já a escolha do termo uso de força insinua o contrário, é dizer, que tal uso se dá num contexto em que existe sanção de autoridade competente (legal ou legítima), e em função disso esse uso está sujeito a limitações (em termos de sua conveniência ou racionalidade). Só assim pode-se identificar um determinado ato como violência ou, no caso contrário, como uso de força.

Como um experimento mental, pode-se imaginar uma determinada ação: a sujeição física de uma pessoa por outra, por exemplo, uma imobilização. A ação física em si mesma nada nos diz sobre sua natureza como um ato de violência ou como um exemplo de uso de força. Seria um ato violento se fosse um ato desautorizado (por exemplo, quaisquer duas pessoas numa briga) ou se o modo de aplicação fosse julgado impróprio (por exemplo, um policial que sujeita uma pessoa idosa quiescente como se ele ou ela fosse um adulto em pleno vigor físico, oferecendo resistência). Mas o mesmo ato seria visto como um exemplo de uso de força se fosse autorizado (por exemplo, um policial que sujeita um suspeito que resiste) ou 
comensurável com o que é julgado apropriado (por exemplo, um pai que sujeita uma criança difícil).

Só esse entendimento permite que se possa dar algum significado a construções tais como "violência policial”. A recusa desses entendimentos conduz ao paradoxo. Por um lado, seria necessário admitir que qualquer ato de força, independentemente do contexto, seria violento, e assim "violência policial" seria redundante. Por outro lado, a se admitir que qualquer ato de força sancionado pela autoridade seria automaticamente uso de força, então "violência policial” seria uma contradição.

\subsubsection{Uso de força}

O que se entende por uso de força, em si mesmo, parece exigir clarificação adicional. O termo uso de força tem que compreender tanto o ato concreto quanto o seu potencial, em qualquer circunstância. Dito de outra forma: o ato físico de força e a possibilidade desse ato são, desse ponto de vista, partes de um mesmo todo: o uso de força.

Como um experimento mental, tome-se um uso cotidiano de força, que pode ser encontrado em qualquer policial armado. Argüir que só se tem uso de força quando a arma é disparada é perder de vista o que é a utilidade da arma em sua essência.

O uso da força não se resume ao emprego concreto da arma para dirigir energia numa ação física - no caso, um projétil. A arma no coldre, e a medida de uso de força que ela contém, é usada na exata medida em que qualquer um, diante de um policial armado, leva em conta o fato de que a arma está lá, e em função disso, modifica seu comportamento. Esse uso é real, e é uso de nada mais que um potencial, e ainda é indubitavelmente um uso na exata extensão em que modifica o comportamento de outrem.

A ameaça no contexto das relações internacionais também só é uso de força na medida em que esteja associada a um potencial tangível. Isto é, uma ameaça vazia de possibilidade de materialização, seja por ausência de capacidade concreta (não se tem meios), seja por ausência de credibilidade (não se crê que o meio, mesmo que disponível, venha a ser usado) é apenas um blefe. O uso de ameaças é um exemplo de uso de força na medida em que possa, de fato, alterar comportamentos.

Considerem-se os diferentes efeitos da ameaça de um mesmo policial de que vai atirar sobre o comportamento de outrem quando: i) tem a arma em punho e mira noutrem; ii) tem a arma em punho, mas apontada para cima; iii) tem a arma no coldre e a mão sobre ela; iv) tem a arma no coldre, mas suas mãos estão distantes; v) anuncia que tem uma arma no carro, longe de onde está; ou vi) anuncia que tem uma arma no armário e que irá buscá-la. 
Esses diferentes efeitos resultam de termos diversos da utilidade do potencial da força enquanto uso de força, e se aplicam a qualquer situação. É essa diferença de potencial que distingue o efeito da posse do mesmo meio de força em diferentes situações, por exemplo no contexto de uma missão de paz.

Considere-se efeito da ameaça de chamar apoio aéreo sobre um determinado grupo armado quando i) as aeronaves armadas sobrevoam o local; ii) sabe-se que as aeronaves estão prontas a responder a um chamado num determinado tempo ou iii) sabe-se que as aeronaves chegarão em uma semana à área de operações; pondere-se o que significa se, em qualquer um desses casos, que a) a força está autorizada ao uso de ataques aéreos quando necessário; b) a força só pode lançar mão de ataques aéreos depois de um ato agressivo direto; c) o uso de ataques aéreos depende de autorização de parte do QG da ONU em Nova Iorque ou d) o uso de ataques aéreos é proibido.

Em todos os casos, o entendimento de "uso de força" tem que incluir seus aspectos concretos e potenciais ou ser, simplesmente, inútil.

\subsubsection{Guerra e paz}

Particularmente no que se refere ao tratamento de Missões de Paz ou, numa tradução mais literal, de Operações de Manutenção da Paz (Peacekeeping Operations - PKO), a distinção entre paz e guerra é condicionada por entendimentos politicamente determinados e, até, por expedientes administrativos. É preciso recuperar a perspectiva fenomenológica da guerra e da paz para que se possa tratar de PKO enquanto objeto de consideração científica.

Por definição política, as Missões de Paz (PKO) não são guerra. Não podem ser descritas como guerra. Sempre devem ser abordadas, tratadas e compreendidas de formas tais que se enfatizem as diferenças entre elas e a guerra.

Isso só é politicamente razoável enquanto se aceita a definição de guerra como um ato que é necessariamente unilateral (ao invés de multilateral), guiado por interesses egoístas (ao invés de altruístas) ou por desígnios agressivos (ao invés de pacíficos), ou ainda associado a agendas políticas que não são julgadas aceitáveis, como a ambição de conquista territorial (ao invés dos que são aceitáveis, como a autodefesa). Assim, por razões razoavelmente evidentes, está muito claro porque as Operações de Manutenção da Paz (PKO), no idioma onusiano, são alguma outra coisa, diferente da guerra. ${ }^{9}$

Também administrativamente, e como reflexo de linhas de política pública politicamente determinadas, uma série de outras ocorrências não são passíveis de serem denominadas como guerras. Devem ser percebidas, descritas e tratadas como sendo outra coisa: como emergências, incidentes de segurança, crises, ações policiais, ou, até operações outras que a guerra (operations other than war OOTW - lê-se “ôtua” ${ }^{10}$. Isso é assim por sólidos motivos administrativos, 
diferenciados em cada Estado ou mesmo em cada burocracia de um mesmo Estado.

Esse jargão especializado distingue os vários tipos de situações e circunstâncias de uso da força. Serve para determinar formas de ação obedientes à agenda política. Tipifica uma dada situação, orientando a tomada de decisão de forma expediente. Como resultado, diante da inclusão de um determinado evento numa destas categorias, tem-se pré-determinadas as esferas de responsabilidade, os modos de ação e procedimentos específicos.

O caráter e o contexto políticos (e administrativos) dessa caracterização são tudo o que empresta às Operações de Manutenção da Paz (PKO) uma denominação distintiva, dando-lhes uma natureza diferente de guerra e diferente da paz $^{11}$. O fato que tais limites são estabelecidos, nesse contexto, arbitrariamente, não os faz menos substantivos ou pertinentes. Mas não devemos introjetar tão profundamente a política, nem nos acostumarmos tão intensamente ao hábito, nem ainda nos familiarizarmos assim tão completamente com expedientes administrativos até o ponto em que percamos a capacidade de ver o que é essencial em PKO. Porque agir assim é perder a capacidade de dar conta de PKO como fenômeno.

Esse artigo aceita a definição de guerra como expresa por Clausewitz, de que a "guerra é... um ato de força para compelir ${ }^{12}$ nosso inimigo à nossa vontade"13. Nesse ponto em diante situa-se explicitamente nos Estudos Estratégicos; e como resultado vai se esposar, como cônjuge, uma definição negativa de paz como a ausência de guerra ${ }^{14}$.

A discussão policial admite considerações análogas, e se beneficia de muito do que já foi exposto até aqui. Politicamente, o que quer que a se faça numa PKO não pode ser o provimento da ordem pública, a garantia da lei ou a administração da justiça. Por definição política, esses são atributos exclusivos dos Estados. A ONU não possui, nem pretende para si, os atributos de um Estado. Logo, quando atividades que são precisamente essas têm lugar sob a égide e com o respaldo de uma PKO, elas necessariamente têm que ser outra coisa.

Administrativamente, a questão é, em larga medida, deixada de lado. Apesar de considerações evidentes sobre a necessidade de se levar em conta os desejos e valores das comunidades nos territórios, na prática estabelece-se um arranjo expediente. Ou bem se assume, sem maiores percalços, a tarefa nos termos dos países de origem das forças, ou se faz "vista grossa” à propriedade ou impropriedade de arranjos locais.

Na prática, a questão policial se quebra numa dicotomia. Por um lado, vive-se a realidade do provimento da ordem pública local por quaisquer arranjos entre os locais, as forças de paz ou a componente policial da PKO. Por outro lado, dá-se continuidade às práticas vigentes (ou, de toda forma, para além da PKO) de questões de lei e de administração da justiça. Exatamente essa medida de omissão e dualidade impediu que se construísse até mesmo um arcabouço pseudo-conceitual. 
Portanto, pode-se tomar os termos provimento da ordem pública, respaldo da lei e administração da justiça em seu significado usual.

Pode-se ver, portanto, porque essas preliminares eram inevitáveis e foram necessárias. Sem esses esclarecimentos, seria muito fácil desviar o ponto que se apresenta a seguir pelo argumento (que espera-se ter refutado) da inaplicabilidade intrínseca quer da teoria da guerra, quer da teoria de polícia, de tomarem PKO como seu objeto. Mais ainda, dá-se conta da impropriedade do pleito de um estatuto teórico próprio e distintivo para o tratamento de PKO, ao se indicar que as bases dessa distinção são políticas ou administrativas e não fenomenológicas ${ }^{15}$.

Só com o esclarecimento do que se entende por força e violência, por uso da força em seus aspectos concreto e potencial, por guerra e por paz pode-se estar numa posição da qual abordar o fenômeno de PKO. Mas isso requer, ainda, um breve reconhecimento das trajetórias políticas, doutrinárias, e conceituais com que se tentou enquadrar as Missões de Paz nas últimas décadas.

\subsection{Trajetórias no estudo de $P K O$}

Apesar de muitos esforços, ainda não se chegou a uma formulação que permitisse classificar, categorizar e explicar uma dada Missão de Paz (PKO) no contexto de todas as demais de maneira clara e útil. Existem ao menos três trajetórias políticas, doutrinárias e conceituais que convergem no fluxo que produziu o que se poderia denominar como sendo a área de "estudos de PKO".

É oportuno que se delineiem as origens e o estado atual de cada uma delas ${ }^{16}$. Por um lado, isso é feito por meio de uma descrição de cada uma destas trajetórias enquanto caminhos relativamente estanques, o que é uma simplificação. Por outro lado, essa exposição não deve ser tomada como o relato da trajetória de qualquer indivíduo ou instituição, embora, evidentemente, indivíduos e instituições tenham papel nas trajetórias que se seguem ${ }^{17}$.

A primeira trajetória poderia ser denominada "internacionalista”. Essa denominação busca descrever o trabalho em direção a um conjunto particular de objetivos políticos para a comunidade internacional, tanto quanto suas componentes conceituais e doutrinárias. Essas metas podem ser descritas, de forma abrangente, como a busca por um mundo mais pacífico, mais equânime e mais justo.

A agenda e os métodos específicos dessa trajetória variam em função de juízos políticos de sua eficácia e oportunidade. Mas a questão da regulação multilateral, expressa em regimes, acordos, leis e mecanismos robustos de mediação poderia ser tomada como sua característica mais marcante. Não seria completamente inadequado descrever o ponto comum das várias linhas dessa trajetória como sendo a implementação planetária da Declaração Universal de Direitos Humanos. Desde o ponto de vista da trajetória internacionalista, a ONU em geral e as PKO em particular são tomadas nem tanto pelo que foram, ou mesmo pelo que são, mas antes pelo que podem vir a $\operatorname{ser}^{18}$. 
A segunda trajetória segue um caminho mais institucional, mais explicitamente associado às demandas das forças armadas e dos governos dos Estados. Também inclui trabalhos produzidos em think tanks e instituições acadêmicas, tanto públicos quanto privados. A segunda trajetória é principalmente, mas não exclusivamente, orientada pela necessidade de nortear o uso das forças armadas e dos demais instrumentos do Estado em prol de objetivos políticos nacionais. Pode ser melhor descrito por uma de suas partes, uma linha forte em sua construção.

O início dessa linha poderia ser identificado com o problema da insurreição no contexto da Guerra Fria, embora se pudesse buscar raízes mais antigas nas “pequenas guerras” coloniais ${ }^{19}$. Desse início, desdobrou-se uma percepção mais ampla desse tipo de conflitos como parte da categoria "Conflitos de Baixa Intensidade" (low intensity conflict, LIC). O fim da Guerra Fria alargou ainda mais o objeto de preocupação, e foi expresso na idéia de operações (militares) que não a guerra (military) operations other than war, (M)OOTW - pronuncia-se (m)ôtua), o que permitiria denominá-la da trajetória "alternativista".

Dentro do enquadramento geral de OOTW, identifica-se um ramo em particular, o de Operações de Estabilidade e de Apoio (stability and suppport operations, SO and $\mathrm{SO}$ ), onde se trata de muito do que se considera, desde a perspectiva da ONU, como sendo PKO. Há, claro que, várias outras perspectivas que incluem ou excluem aspectos particulares (por exemplo, infra-estrutura, saúde, desenvolvimento, etc), e ainda os recortes que diferenciam muito claramente entre OOTW no interior e no exterior do território de um Estado por suas próprias forças e agências.

A natureza formal, organizacional e hierárquica dos documentos nos quais esses pontos de vista são usualmente apresentados pode engendrar a sensação de uma completitude conceitual ou, até, de uma suficiência autofundante e estrutural. É preciso não tomar os imperativos de conveniência administrativa ou jurisdição estatutária ali contidos como se fossem um arcabouço teórico, ou mesmo como se tivessem sido escritos com tal ambição ${ }^{20}$.

Da mesma forma, não é adequado que se tratem as definições (operacionais e legais) neles contidas como se fossem conceitos científicos, embora haja trabalhos científicos em outras linhas dessa trajetória ${ }^{21}$. É pertinente observar que a linha alternativista faz parte de um esforço muito maior que o de enquadramento de PKO, ou mesmo da circunscrição das OOTW. É preciso enfatizar como esses esforços são parte de um todo bem mais amplo, que busca adaptar o arcabouço intelectual de segurança e defesa em harmonia com as realidades do mundo pósGuerra Fria ${ }^{22}$.

A terceira trajetória é talvez a menos organizada em termos institucionais, sem que isso deva ser entendido como um juízo de sua menor relevância em relação às duas primeiras. Nasce dos trabalhos de estudos de paz e de resolução de conflitos, 
que ganharam um espaço no próprio Século XX. Essa trajetória originou-se do interesse de dar conta dos conflitos desde suas causas ou raízes; nesse sentido pode-se nomeá-la como a trajetória "estruturalista".

Acabou por ir além dessa preocupação inicial. Trouxe contribuições substanciais sobre questões como o controle de armamentos, o desarmamento, ou ainda sobre os requisitos e técnicas de negociação no cenário internacional. O contexto de tais iniciativas resultou do desejo para oferecer uma alternativa ao que se percebia como sendo a paralisação quase completa dos interesses de segurança e da cristalização dos dilemas resultantes da Guerra Fria. Muito do se sabe hoje sobre as exigências e técnicas da resolução de conflito desde diferentes perspectivas culturais é fruto de trabalhos da trajetória estruturalista.

Até certo ponto, não parece completamente inadequado ver essa passagem na trajetória estruturalista, desde os estudos de paz até o tratamento de PKO, como sendo um espelho da mesma passagem na trajetória alternativista desde LIC até OOTW/PKO. Ambas sendo, até certo ponto, instrumentos de metas propostas na trajetória internacionalista. É menos claro como as concepções fundadoras dos estudos de paz e resolução de conflito, que contêm muitos elementos de auto-sacrifício e de passividade, foram modificadas para dar conta das exigências de segurança em PKO.

Ainda assim, pode-se argumentar que os conteúdos originais da trajetória estruturalista estão muito próximos do próprio cerne e razão de ser da ONU. Com essa percepção, a aparente falta de clareza da trajetória estruturalista se explicaria exatamente por sua proximidade ao centro do próprio assunto, isto é, que deve ser o papel da $\mathrm{ONU}^{23}$.

É possível esboçar algumas características da situação presente quando se admite a existência e contribuições discrepantes destas três trajetórias. Por um lado, há elementos ricos e inovadores, associados e instrumentados por posições políticas claras e maduras, que se apóiam em conhecimentos sofisticados das expectativas táticas. Daí se podem derivar prontamente perspectivas estratégicas consistentes e análises críticas de primeira água.

Porém, por outro lado, como sua história sugere, inexiste concordância significativa em termos de conceitos e perspectivas. Evidenciam-se direções incompatíveis ou até mesmo contraditórias em termos do que sejam as expectativas sobre PKO, seu papel, possibilidades, exigências, métodos, e resultados.

\subsection{O valor da teoria}

A tarefa de aperfeiçoar essa mistura, destilando-a em formulações sólidas, é uma das tarefas mais urgentes diante dos estudiosos. Qualquer formulação com essa ambição tem um requisito inescapável: tem que permitir a caracterização do que é normal em PKO, no sentido amplo de missões de paz. 
Dito de outra forma, essa proposição deve ser capaz de tratar não apenas as missões de paz historicamente acontecidas, mas todas as que sejam possíveis. Tal empreendimento vai além do estabelecimento de instâncias de troca, ainda que possa ser necessário começar por tais instâncias. Um primeiro passo é o de construir um entendimento que distinga os aspectos compatíveis ou incompatíveis dos arcabouços em vigor. Uma revisão muito sumária do que tal um esforço requereria está delineada nas três trajetórias descritas.

Aqui é importante marcar que o tema substantivo desse esforço é a construção da fundamentação propriamente teórica de $\mathrm{PKO}$, que parece a única vereda pela qual se atende à exigência da descrição da normalidade. Só essa descrição pode nos permitir caracterizar, antecipar e descrever as exigências, métodos, limitações e resultados das PKO em geral; e por essa via permitir o reconhecimento do que é distintivo, específico e único em qualquer PKO em particular.

Esse artigo busca avançar rumo a tal formulação ensaiando duas percepções do objeto PKO a partir de estruturas teóricas razoavelmente estabelecidas. Desse modo, espero iluminar como tais percepções podem ser de uso para um tratamento teórico mais inclusivo e completo de PKO.

É comum que nos dias de hoje se espere que um artigo desafie paradigmas existentes, o que seria, até onde se entende a meta desse texto, prematuro. Alternativamente, também se é constantemente provocado a enfocar problemas atuais por uma abordagem afinada com as ênfases temáticas do momento. Esse artigo não faz nem uma coisa nem a outra. Limita-se a compartilhar alguamas considerações de como PKO como um fenômeno pode ser descrito a partir de duas teorias distintas e, usualmente, separadas, a saber a teoria da guerra e a teoria de polícia. Mais ainda, isso é feito de exercícios muito simples, aplicando primeiro, uma e depois, a outra, às operações de manutenção da paz (PKO).

\section{PKO são guerras de coalizão}

BURGUNDY: My duty to you both, on equal love, Great Kings of France and England! That I have labour'd, with all my wits, my pains and strong endeavours, to bring your most imperial majesties unto this bar and royal interview, your mightiness on both parts best can witness. Since then my office hath so far prevail'd, that, face to face and royal eye to eye, you have congreeted, let it not disgrace me, if I demand, before this royal view, what rub or what impediment there is, why that the naked, poor and mangled Peace, dear nurse of arts and joyful births, should not in this best garden of the world, our fertile France, put up her lovely visage? (...)

KING HENRY V: If, Duke of Burgundy, you would the peace, (...) you must buy that peace with full accord to all our just demands.

Henry V, Ato V, Cena 2. 
Propõe-se o seguinte para abordar as operações de manutenção da paz (PKO) desde a teoria de guerra: apresenta-se brevemente a teoria de guerra; a isso se segue a demonstração de que as operações de manutenção da paz (PKO) enquadram-se na definição clausewitiziana de guerra, o supracitado “Guerra é... um ato de força para compelir nosso inimigo para fazer nosso vontade ${ }^{24}$ ”. A partir dessa demonstração, pode-se perceber que PKO são uma forma de guerra de coalizão, o que permite apresentar quais seriam suas características distintivas. Desde essa perspectiva, procede-se então a algumas considerações políticas, táticas e estratégicas.

\subsection{Uma visão sumária da teoria de guerra ${ }^{25}$}

A realização mais extraordinária de Clausewitz é freqüentemente aceita como óbvia, o mais sincero elogio à qualidade de seus argumentos, ainda que usualmente inconsciente. No Da Guerra o povo sai do pano de fundo e se revela no centro mesmo da guerra. Nenhum outro autor antes dele o havia percebido. Nenhum autor depois dele pode ignorá-lo.

Em toda a literatura que o antecedeu, as populações, os povos, eram tratados e descritos como parte do ambiente. Podiam ser hostis ou amigáveis, podiam explicar o sucesso ou justificar o fracasso, mas ninguém via valor em sua opinião ou envolvimento. $\mathrm{O}$ embate entre uns poucos seletos resolveria a questão da posse e controle do território e dos bens humanos ali contidos. O povo era só parte do saque, ocasionalmente um benefício ou mais freqüentemente uma amolação ${ }^{26}$. Isto definitivamente não pode mais ser visto assim a partir Da Guerra: o povo é parte intrínseca, inegável, irremovível da guerra. Se o povo se dispõe a resistir, pode seguir adiante sem exércitos, ou até mesmo sem governos.

A contribuição de Clausewitz em termos de método, por outro lado, é freqüentemente pouco apreciada. Trata-se de uma abordagem que segue passos simples: construa-se um conceito do fenômeno em análise; examine-se plenamente suas conseqüências lógicas; observe-se a realidade. Onde a realidade discordar da expectativa lógica, explique-se a discrepância logicamente, mas sem confrontar ou desautorizar o dado de realidade.

Logicamente, a guerra deveria ser absoluta, um pulso instantâneo de violência que usasse o máximo de força e que empregasse todos os recursos disponíveis para dispor da maior força possível. Seu resultado deveria ser sempre o desarmamento completo e definitivo de um dos lados, entregando-o de uma vez para sempre à vontade do outro. Mas a guerra na realidade nunca é instantânea, nunca usa o máximo de força, nunca converte todos os recursos disponíveis, e usualmente termina antes que um dos lados esteja inteiramente prostrado diante de seu oponente; seus resultados raramente são finais ou definitivos. 
Clausewitz distingue então os dois tipos de guerras reais: as que são limitadas e as que não o são. A diferença entre um e outro tipo de guerra reside no resultado da dinâmica do que desejamos que nosso inimigo faça e o quanto ele está disposto a resistir à nossa vontade. A partir de seus estudos históricos, afirma que as guerras terminam antes - freqüentemente, bem antes - que qualquer um dos lados estivesse prostrado diante de seu inimigo. Por prostrado entende-se incapaz de resistir à vontade de seu oponente, isto é, desarmado, impotente: portanto, impossibilitado de fazer frente à compulsão, pela força, para o que quer que seu oponente deseje.

A questão da distinção entre as guerras que são e não são limitadas reside precisamente na medida do empenho do inimigo de resistir à nossa vontade. Se o que dele desejamos exige apenas que vençamos uma parte de suas forças (uma guerra limitada) ou, ao contrário, se o que desejamos só estará a nosso alcance quando o inimigo estiver prostrado diante de nós (uma guerra ilimitada).

Embora Clausewitz não use o termo "guerra ilimitada", Corbett (1988) realiza essa passagem sem maiores explicações. Ela me parece apropriada e consistente, particularmente desde que serve de maneira clara para distinguir os dois tipos de guerra real, servindo ainda para apontar incisivamente o equívoco de querer-se tomar a guerra não limitadas como sinônimo da "guerra absoluta" que só existe na pura aplicação lógica do conceito de guerra nos primeiros passos da apresentação de Clausewitz.

Tudo isso se aplica a qualquer guerra, desde que entenda-se a guerra nos termos de "um ato de força para compelir nosso inimigo a fazer nossa vontade". Essa formulação aparentemente simples é de surpreendente robustez e atualidade. Em qualquer guerra, é necessário dispor de três elementos - o que se deseja (a nossa vontade), quem a isso resista (o inimigo), e uma forma particular de lidar com essa recalcitrância: o ato de força. Nesse último radica o que empresta a guerra sua especificidade, permitindo perceber a guerra como a política armada. É o ato de força, cuja condição de possibilidade são os meios de força, que dá significado descritivo e conclusivo a que a guerra seja continuação da política com o acréscimo dos meios de força. Guerras frias, crises, guerrilhas, e, como discutirei mais adiante, operações de manutenção da paz (PKO) - o que são senão guerras?

Aqui é necessário dar conta da prática de se querer categorizar as guerras a partir de sua "intensidade”. Esse é um dispositivo expediente, de natureza administrativa, cujo propósito é precisamente o de associar automaticamente cada “intensidade” a uma dada resposta pré-determinada. Cada uma destas respostas determina o envolvimento diferenciado de diversas agências, estabelecendo linhas de comando e responsabilidade, operando sob um conjunto de direções e nomeando constrangimentos pré-estabelecidos. Permite, portanto, segregar antecipadamente determinadas contingências, determinados meios de força e até determinados 
inimigos para um tratamento específico. A tentativa de transpor esse expediente administrativo para o arcabouço de uma estrutura conceitual acaba provocando equívocos e levando a erros inteiramente dispensáveis.

Leitores desavisados, por exemplo, tomam a representação gráfica dessa segregação administrativa expediente como uma proposta taxonômica. Perdem de vista o seu caráter arbitrário e circunstancial. É preciso afirmar, portanto, que não existe nenhum "espectro de conflitos" 27 — existe guerra ou paz.

Guerra, sempre que os resultados atuais ou potenciais de combate, isto é, do uso de força, são uma consideração que modifica o comportamento dos envolvidos, não importa o quão brandamente. Paz, quando, ao contrário, tais considerações não têm qualquer efeito no comportamento dos envolvidos. Ordinariamente, a paz dá conta da maioria esmagadora dos relacionamentos internacionais, em temas tão diversificados quanto como o comércio, a cultura ou a diplomacia. Sabemo-lo na prática: uma "crise diplomática” afirma que não se considera o uso de força. Uma crise é apenas uma denominação politicamente expediente para uma guerra limitada.

Assim pode-se compreender, como se apresentou nas preliminares, que pode não ser politicamente oportuno chamar uma crise de guerra; ou uma operação de contra-guerrilha de guerra; ou o abalroamento de um navio pesqueiro estrangeiro em algum lugar do Círculo Ártico de guerra; ou a reintegração de posse de um arquipélago no Atlântico Sul de guerra. Pode até ocorrer que não seja politicamente útil recorrer aos mecanismos jurídicos associados à formalização de tais ocorrências como guerras. Mas existe a ambição de modificar o comportamento de outrem pelo ato de força. Em essência, todas essas instâncias são atos de força que buscam compelir outros à nossa vontade. Rigorosamente, elas são guerras.

É crucial que se perceba que tudo o que se expôs até aqui afirma a onipresença de soluções alternativas ao ato de força, antes, durante e até depois do recurso à força. Alternativas que sejam negociadas, barganhadas, discutidas, compradas ou vendidas entre as partes. Essas alternativas existem intrinsecamente à guerra sempre que o que se deseja não exija que prostremos nosso inimigo diante de nós para que o obtenhamos. Se o que se deseja não é algo que nosso inimigo só concederá depois de prostrado, então persistem as alternativas da barganha de interesses discrepantes, de julgamento de parte a parte do que está em conjunto, do que levou a que um dos lados recorresse à força e que o outro resistisse. $\mathrm{O}$ propósito da guerra é a paz. O objetivo da guerra é uma paz “melhor”, mais afeita aos interesses de quem a inicia, ou de quem a vence; ou simplesmente uma paz, sempre que ambos os lados sentem que eles ganham mais pela cessação que pela continuação de hostilidades.

Assim, para retornar à epígrafe dessa parte, pode-se comprar uma paz, dentro de alguns limites. Depende tanto do quanto se está disposto a pagar - e do quanto o inimigo valora o que dele se quer. Os termos dessa barganha serão 
modificados pelo que pode ser arriscado, ganho ou perdido no combate; pela expectativa do que pode ser arriscado, ganho ou perdido ao longo do tempo, se as hostilidades prosseguem; pela expectativa de resultados mais ou menos favoráveis na continuidade do uso da força, em função das perspectivas de alteração da correlação de forças de ambos os lados; e ainda pela perspectiva de se ver prostrado diante do inimigo em contraste com o que ele deseja de nós, ou nós dele. Guerra é política, à qual se pode acrescentar os meios de força. Ou ainda, guerra é política armada.

Regras de Engajamento (Rules of Engagement - ROEs) são a forma pela qual se condicionam as formas de uso da força de maneira a garantir que o método de seu emprego não conflite com os fins pretendidos. ROEs são estabelecidas principalmente, mas não exclusivamente, a partir de considerações políticas quanto aos resultados colaterais do uso da força. Buscam apenas e não mais do que orientar o efeito do ato de força de acordo com os objetivos políticos pretendidos. Mas isso é o suficiente, porque tanto os beligerantes quantos os demais levam em conta não apenas os motivos que levam ao uso de força, mas também as formas pelas quais se usa da força.

De fato, do ponto de vista da pura razão, os Estudos Estratégicos enquanto uma disciplina científica vão além do entendimento vigente de que o atributo político pertence aos Estados pós-Westfalianos. Que objetivos políticos pertençam monopolisticamente a Estados é uma distinção arbitrária, e algo questionável, na primeira década do Século XXI. Esse entendimento dá substância à compreensão jurídica da Soberania mais do que a qualquer outra coisa.

Uma definição estreita de que a política é (ou deveria ser; não importa) um atributo exclusivo de Estados é recente e pode ser reconhecida como uma questão de circunstância histórica. Ainda que seja uma definição arbitrária e, portanto, artificial, isso não a faz (nem precisa fazer; não importa) menos real. O ponto a se ter em mente é que essa definição não reflete a essência do assunto, e exclui muito do que poderia ser de valor para um entendimento mais completo do tema.

Uma compreensão mais larga de política como o relacionamento de grupos, por si só, iluminaria a abrangência e pervasividade da estrutura clausewitiziana, e serve para que se possa aferir em novas bases o juízo que se tenha de seu valor. Isto é particularmente relevante na consideração de Missões de Paz (PKO), onde grupamentos políticos (que podem se armar assim que decidam que a alternativa da força lhes interessa ou serve) que não se deseja reconhecer como Estados, ou que não são Estados, ou podem mesmo nem querer ser Estados ou parte de Estados, têm que ser considerados.

Na teoria da guerra, política, tática e estratégia são onipresentes em todo e em cada ato bélico. Essa repartição da guerra em dimensões ${ }^{28}$ política, tática e estratégica é um recorte analítico. Busca distinguir os objetivos (política), o uso de 
força no combate (tática) e o uso dos combates em prol dos objetivos (estratégia). Não podem ser separados, a menos, usualmente, nas considerações táticas mais elementares.

Realizemos um experimento mental. Imaginemos um combatente individual, armado com um rifle, lutando. Atirar em tiro simples ou rajada, num dado momento, pode considerar apenas elementos táticos. É dizer: a decisão de atirar de uma ou de outra maneira pode ser tomada exclusivamente com base no efeito que se deseja produzir sobre a força inimiga. Mas nem sempre.

Se se tem pouca munição, então considerações propriamente estratégicas - orientadas não pelo efeito da força no combate, mas sim pela necessidade de manter-se capaz de combater, isto é, de ser capaz de seguir usando os combates em prol dos objetivos políticos - irão determinar o uso do tiro simples. Se se está atuando num território aliado, por outro lado, pode-se exigir que todo tiro de parte de nossas forças seja feito com tiro simples, de maneira a minimizar baixas colaterais ou acidentes. Aqui tem-se uma restrição política - o uso da força não deve atingir (ou alienar) a população aliada.

Note-se que se poderiam ter considerações estratégicas - máxima velocidade de avanço em território inimigo; ou políticas - intimidação da população do território ocupado; que determinariam uma preferência pelo tiro em rajada. Percebe-se assim como as Regras de Engajamento (ROEs) servem como instrumento formal pelo qual considerações políticas (e estratégicas) são transmitidas ao longo das forças, orientando a sua tomada de decisão tática. O combatente de nosso exemplo não precisa, necessariamente, estar informado do raciocínio político ou estratégico que determina a predisposição pelo tiro simples ou em rajada basta que esteja informado da ROE em vigor para que suas ações, e das forças como um conjunto, sigam a forma desejada.

O combate, até mesmo quando ele não acontece, está ao centro do fenômeno bélico. A consideração do resultado esperado no combate pode ser o suficiente para um dos lados decida-se a não combater, ou a ceder a seu inimigo nesse ponto, ou até mesmo a se render sem luta. Um resultado direto de tal uma compreensão, de importância considerável para PKO, é que a observação armada pode assim ser percebida como uma forma de guerra.

Esse sumário da teoria da guerra serve apenas para dar destaque a alguns pontos relevantes para a discussão e realiza um resumo parcial. É seguido pelo inquérito da natureza das operações de manutenção da paz (PKO), buscando responder se ela corresponde à definição de guerra.

\subsection{As PKO são atos de força para compelir outrem à nossa vontade?}

As operações de manutenção da paz (PKO) são atos de força? Em caso afirmativo, são atos de força cuja intenção é o de produzir a quiescência de outrem 
à nossa vontade? Afirmo que ambas as perguntas podem ser respondidas afirmativamente de forma breve, e que as operações de manutenção da paz (PKO) são guerras.

Por um lado, as Forças de Paz não são forças gratuitamente. A sua chegada é distinta da de quaisquer outros num determinado território. Assim, diferentemente de, por exemplo, negociadores, diplomatas, mediadores, ONGs, agências ou mídia, a chegada de Forças de Paz implica em si mesma o uso de força.

É irrelevante sob quais regras de engajamento (ROEs) essas forças deverão atuar. As forças estão organizadas e capazes de combater, independentemente de seu efetivo, equipamento ou quaisquer outras características ou particularidades que se deseja atribuir. A menos que se admita a produção de um paradoxo forças desarmadas.

Por outro lado, pode-se determinar ROEs de tal forma restritivas que é como se as forças não existissem no território. Nesse último caso, caberia perguntar por que elas estão ali. Mesmo nesse caso extremo, tem-se que admitir que, no limite, o instinto de sobrevivência faria com que as forças, nem que indivíduo a indivíduo, usassem de suas habilidades e as armas que pudessem obter para preservar suas vidas ou integridade física.

A idéia de uma identidade perfeita entre um contingente de forças de paz e uma legião de mártires passivos e omissos não se sustenta. É simplesmente a falácia de similitude, em que o resultado deve ser homogêneo com os métodos que o produzem. Assim, independentemente do que se deseje, há que se aceitar o fato de que a chegada das Forças de Paz num território embute, inescapavelmente, inequivocamente, um ato de força.

As PKO são um ato de força contra quem quer que teria usado de força num dado território se as Forças de Paz não estivessem ali. Isto é verdade independentemente do fato das forças de paz virem a combater, ou não; de se poder identificar, ou não, os que teriam usado de força; de se dar às forças de paz ROEs tais que as forças simplesmente existem como testemunhas do que acontece no território e estão impedidas de qualquer ato exceto o de sua estrita autodefesa.

Nesse último caso, o envio de forças de paz se distingue do envio de simples observadores militares exatamente porque forças de paz podem se defender enquanto força combatente e não apenas com as armas pessoais dos observadores em duplas ou pequenas equipes. Isto significa que seu testemunho dos eventos não pode ser fisicamente obstacularizado, que a sua observação, uma observação armada, tem o potencial de ser inevitável, e, portanto, provocar a mudança no comportamento dos que ela (pode) estar observando. E a intenção de se colocar tais observadores armados - o caso extremo, admito, mas por isso mesmo oportuno - não pode ter outro propósito do que produzir essa mudança comportamental. É esse o uso de força que mesmo esse caso extremo contém.

De fato, as Forças de Paz não existem por elas mesmas: são ferramentas de Missões de Paz (PKO). A meta das PKO é precisa e constante, embora o 
conteúdo específico de qualquer PKO individual ou, até, das normas gerais de sua condução não o sejam. Qualquer PKO quer fazer valer "a vontade da ONU”, como expressa num Mandato do Conselho de Segurança ${ }^{29}$.

É irrelevante se tal vontade é aceita ou consentida por todos num dado território (e é concebível que a PKO pudesse ser usada para assegurar a materialização desse consentimento), ou por uma maioria, ou por muitos, ou por poucos ou até por ninguém. Também é irrelevante como se avalia tal vontade, ou as metas que ela estabelece. Não importa, ainda, qual seja a identidade de quem se deseja compelir pelo ato de força, ou que essa identidade seja indeterminada, ou mesmo que o destinatário do ato de força varie ao longo do tempo ou de acordo com circunstâncias. Mesmo que se identifique como objeto da ação a produção de uma determinada condição (por exemplo, a ausência de "conflito armado") como o "inimigo", em cada momento, um determinado conjunto de seres humanos concretos se comportará de maneira indesejável. Realiza-se uma PKO para que eles não (mais) o façam - compelindo, se isso for necessário ou conveniente.

$\mathrm{O}$ uso da força se torna uma consideração depois que Forças de Paz chegam a um território. É teoricamente certo que diferentes métodos serão usados na decisão e orientação do emprego concreto ou potencial da força. É uma questão política que alguns métodos sejam preferidos a outros, que certos métodos ou ações sejam proibidos ou tornados obrigatórios. Haverá um determinante no uso da força subordinado de forma mais, ou menos, explícita aos objetivos políticos a serem alcançados. Isto é precisamente o que se esperaria em qualquer guerra.

Existe uma vontade a ser cumprida, a vontade da ONU; busca-se obter essa vontade pelo ato de força da PKO, que é inseparável das forças de paz que a integram e delas se serve; o objetivo desse ato é o de produzir determinados comportamentos em outros. PKO são atos de força para compelir outrem à vontade da ONU: são guerras.

Cabe agora buscar elementos característicos de PKO desde a perspectiva se sua natureza bélica: isso é feito por meio de considerações políticas, táticas e estratégicas.

\subsection{PKO são guerras de coalizão - considerações políticas}

Missões de Paz são guerras de coalizão, já que a vontade da ONU não encarna um único conjunto de objetivos políticos, nem expressa uma vontade una e própria. A vontade da ONU, nesse sentido, expressa a resultante das vontades de seus Estados-membros em geral, e do Conselho de Segurança em particular. Várias considerações políticas podem ser desdobradas dessa realidade.

Em um mundo de Estados soberanos, as guerras resultam da busca dos interesses desses Estados no sistema internacional. Como resultado, qualquer ação coletiva tem que levar em conta, e deve estar em alguma medida de acordo com, 
os objetivos políticos e prioridades de cada Estado, sopesada a sua importância relativa. Desse ponto de vista, qualquer ação combinada de forças (isto é, de forças de mais de um Estado) é uma guerra de coalizão, e esse entendimento abrange as Missões de Paz (PKO) da ONU.

Os mecanismos precisos pelos quais qualquer uma destas ações será descrita ou caracterizada dependerá de expedientes políticos. Um mesmo conteúdo poderá ser descrito como uma ação da ONU, uma ação sancionada pela ONU, ou uma “coalizão voluntária” de Estados-membros autorizada pela ONU. Essa distinção não é vazia de significado: determina diferentes expectativas e compromissos de natureza política. Mas o caráter essencial de qualquer desses arranjos é apenas o da medida de uma maior ou menor adesão a uma dada iniciativa. A coalizão, ela mesma, não é posta em dúvida.

Qualquer guerra de coalizão experimentará períodos de maior e menor convergência entre os membros da coalizão. Terá que produzir cursos de ação aceitáveis a todos os Estados participantes, num processo de negociação ponderado por uma variedade de fatores. Esses fatores incluem as políticas domésticas e externas de cada Estado, seu poder relativo, sua influência e interesse em qualquer assunto e em qualquer momento dado.

Como sempre em política, esses fatores produzirão situações transitórias: desde aquelas em que todos os membros da coalizão estão em acordo completo (uma situação rara, mas indubitavelmente possível, tão mais urgente seja o assunto sob consideração, e quão mais se aproxime dos interesses dos membros), passando por aquelas em que há uma certa medida de acordo, indiferença ou concessão dessa questão em favor de uma outra, até aquelas em que os membros mais poderosos ou capazes da coalizão apresentam fatos consumados e negociam mais a indiferença do que a adesão dos outros membros.

Nem sempre esse processo produz uma direção única de ação. É perfeitamente possível - até, corriqueiro - que divergências permaneçam mesmo após a decisão formal por essa ou por aquela linha de ação, e que se manifestem em iniciativas e ações divergentes ou, até, francamente contraditórias entre os membros, ou entre iniciativas individuais e o que se apresenta como a resultante da decisão coletiva.

Assim, os assuntos e problemas associados com a discrepância de compromissos, empenho e convergência nas ações dos Estados participantes numa dada PKO não pode, realmente, ser tomada com surpresa ${ }^{30}$. O surpreendente seria o contrário: que as PKO fossem modelos de ação unitária e coordenada. Como guerras de coalizão, é de se esperar que haja custos substanciais na construção de uma unidade de ação, e mesmo esse esforço pode não ser o suficiente para obter a participação de todos os envolvidos na medida desejada.

Trata-se de uma questão presente em toda a história das guerras de coalizão - o que significa que os problemas de PKO, aparentemente intratáveis, podem 
recorrer a esse acervo. Assim, a natureza peculiar do compromisso político revelase como apenas coerente com sua identidade como guerra de coalizão. Com essa perspectiva, é inescapável concluir que a percepção de PKO como algo diverso, distinto, ou ainda "menos que" a guerra pode, de fato, ter contribuído para algumas de suas dificuldades.

Para os fins desse artigo, basta enfatizar as conseqüências teóricas mais imediatas de tal uma situação. A consideração política de PKO sugere três assuntos imediatos: o primeiro diz respeito à natureza dos objetivos; o segundo diz respeito à natureza da oposição, quer dizer, o "inimigo" a ser compelido; o terceiro diz respeito ao contexto político em que as PKO têm lugar, e serve de fato para a proposta de uma tipologia das operações de manutenção da paz.

\subsubsection{Os objetivos políticos de PKO}

Quais são os objetivos políticos da ONU em PKO? Em termos gerais, a resposta poderia parecer muito simples. Toda e qualquer PKO visaria a mesma meta: a produção de uma paz estável num território conturbado ${ }^{31}$. Mas esse entendimento é superficial, e se arrisca a uma percepção falsa do que sejam os objetivos políticos da ONU em qualquer PKO em particular.

As considerações políticas dos objetivos em qualquer PKO que determinam o estabelecimento de uma situação pacífica estável só pode resultar, desde a perspectiva da teoria de guerra, do estabelecimento de um equilíbrio de forças. Só um tal equilíbrio permite que a continuidade da paz seja a melhor opção para os envolvidos (ou, pelo menos, para os envolvidos capazes de alterar essa continuidade).

Considerando que esse equilíbrio de forças será sempre diferente do que existia antes da chegada de Forças de Paz, pode-se perceber que o início de uma PKO determina uma mudança no poder relativo dos beligerantes, sejam eles Estados ou grupos. Acrescentará força a alguns, opondo-se a outros.

Qualquer outra aproximação simplesmente será inócua ou, pior, erigirá as Forças de Paz em apenas mais um grupo beligerante (nem que seja apenas como alvo ou problema para todos os demais). Como resultado, a vontade e a capacidade (particularmente, de apoiar ou resistir a tal mudança no equilíbrio de forças) dos que serão fortalecidos ou debilitados torna-se a consideração política primordial.É desse ponto que se pode perceber como o consentimento de todos os envolvidos (ou, novamente, pelo menos dos envolvidos capazes) não é tanto uma condição de possibilidade quanto uma conveniência política para a ocorrência de uma $\mathrm{PKO}^{32}$.

Parece-me que a questão colocada por Betts (1995): "quem governa ao final?” remete diretamente ao cerne do que seja o objetivo político de toda $e$ qualquer PKO. Independentemente de qualquer outra consideração, é necessário que haja uma decisão clara sobre esse resultado político primordial. A postergação 
dessa decisão não serve a nenhum propósito. Logo, ela deve estar presente no momento mesmo em que se considera a elaboração de um Mandato, em que se identifica a necessidade de uma PKO. A ausência dessa decisão compromete não apenas a identificação demais objetivos políticos que se queira alinhavar; arrisca sabotar o próprio desenrolar da PKO, destruindo sua possibilidade de sucesso.

Reconhecem-se dois possíveis critérios. Por um lado, se a meta primeira da ONU for a produção de um arranjo que assegure paz e estabilidade, então é mais fácil e mais econômico decidir pragmaticamente. Arriscando-me a simplificar os argumentos apresentados por Betts, tomar-se a solução alexandrina ${ }^{33}$ : apoiar e ungir "o mais forte”. Assim, por esse critério, quem quer que possa produzir a hegemonia na região com o concurso das forças de paz deveria ser quem governa ao final.

Por outro lado, se a meta primeira da ONU for a predisposição por um determinado arranjo particular de governo para a produção da paz e da estabilidade, então a questão passa a ser a identificação de quem possa produzir esse arranjo. Imagina-se que isso corresponde a uma seleção que ignora a preponderância relativa dos grupos no conflito, e que elege aqueles com os quais se tem uma afinidade política - por exemplo, os que exposam uma forma democrática de governo; mais amplamente, os que subscrevem os termos políticos valorados pela ONU.

Se for esse o critério, então as PKO - e as Forças de Paz - devem ser concebidas e dimensionadas para levar ao poder aqueles com quem se simpatiza, incrementando suas forças para que sejam eles que acabem no governo, ao final. Evidentemente que isso significa que a adoção desse critério pode implicar em custos (e a necessidade de forças) substancialmente maiores que o primeiro.

$\mathrm{O}$ apoio ao mais forte é expediente e econômico em termos de recursos e forças. Mas pode implicar no apoio a quem não compartilha, necessariamente, de perspectivas que se considerem desejáveis ou, até aceitáveis (novamente, por exemplo, democracia). Isto significa que, do ponto de vista pragmático das políticas nacionais dos vários membros da coalizão, que a questão passa a ser a de apresentar esse resultado como um mal menor. O apoio a um arranjo viável mas a um (a forma de) governo indesejável.

$\mathrm{O}$ apoio àqueles com os quais se tem simpatia política enfrenta o fato de que esses podem não ser os grupos mais fortes. Isto significa que, do ponto de vista pragmático de políticas nacionais dos vários membros da coalizão, a questão passa a ser a de ter que defender um compromisso que exigirá mais empenho, será mais caro e mais difícil.

A maioria dos governos democráticos tem limites na medida do apoio que pode dar a formas não democráticas de governo. No limite tem que atuar de forma a poder responder de forma positiva à pergunta de seu eleitorado: Essa PKO em particular permitirá que as pessoas no território vivam de maneira a serem "felizes como nós?” 
Eu subscreveria essas considerações e iria mais adiante, com o benefício da compreensão de PKO como guerra. A próxima pergunta a ser feita com relação aos objetivos políticos da ONU em uma PKO é, portanto, "que tipo de guerra ela é?” O desenvolvimento aqui é simples. Independentemente do critério e da decisão tomada com relação a quem governa, ao final, é preciso esclarecer se a decisão de realizar uma operação de manutenção da paz, de colocar em campo forças de paz, levará a uma guerra limitada ou uma guerra ilimitada.

A questão é política: trata-se de estimar a resistência que será colocada diante da meta de se levar ao poder um determinado grupo (ou arranjo de grupos). Isso permite que o tema seja tratado com precisão. Há dois casos.

Há expectativa razoável de que se produza uma situação aceitável por todos, que produz o resultado desejado, colocando quem se deseja no poder? Isto é, espera-se que o uso dos recursos disponíveis por meio de da PKO (inclusive o uso de força quando necessário ou oportuno) seja suficiente para criar uma situação na qual esse resultado seja aceito por todos os atores relevantes no território? Se for esse o caso, então se contempla uma guerra limitada.

Se não se tem tal expectativa, isso significa que será necessário prostrar pelo menos alguns dos grupos existentes antes que eles venham a aceitar esse resultado. Se for esse o caso, então se contempla uma guerra ilimitada.

Com o benefício destas considerações, pode-se perceber como, apesar da aparência de uniformidade que o objetivo político geral de produção da paz e estabilidade poderia sugerir, de fato escolhas políticas e a consideração política do tipo de guerra - do tipo de PKO - que será necessário para obtê-las permitem compreender que se terá uma gama de resultados possíveis.

\subsubsection{A identidade do "inimigo"}

Um ponto principal da própria idéia de operações de manutenção da paz (PKO) é seu compromisso com o consentimento e a imparcialidade. A fragilidade desse posicionamento é simples de expor. É impossível construir o que quer que seja se o entendimento de consentimento for tomado como um requisito de consenso permanente ${ }^{34}$. É impossível ser imparcial e responder à pergunta sobre quem governa, ao final. O desejo de preservar esses elementos principiais levou a dois expedientes políticos.

O primeiro foi o de se aceitar o consentimento em bases qualitativas muitas vezes, a sanção dos grupos mais fortes ou, até, apenas dos grupos com os quais se tem simpatia. Indo mais além, uma vez que se considere que foi dado o consentimento, não parece haver mecanismo prático para o teste de sua continuidade, a menos do estabelecimento de um governo, que governa, ao final. Nesse sentido, PKO que têm lugar como forças de interposição entre Estados beligerantes beneficiam-se da clareza que corresponde ao desejo explícito dos governos envolvidos por sua continuidade ou término. 
O segundo expediente foi o de reconfigurar a imparcialidade, distinguindoa da neutralidade, por um lado, e despersonalizando-a, por outro. Em termos gerais, passou-se ao reconhecimento de que qualquer PKO "nunca é neutra" 35 , embora por definição elas sejam reafirmadas como sendo imparciais. A não neutralidade de PKO não foi aceita com facilidade, mas é evidente que o conteúdo do mandato de uma PKO - que determina um resultado - torna impossível que ela possa ser neutra em relação a esse resultado. Percebe-se que o exercício de "bons ofícios" ou de peace making pode, e freqüentemente é, despido de qualquer compromisso com resultados ${ }^{36}$.

A despersonalização da imparcialidade, a seu turno, ganhou forma na idéia de que "o inimigo é o conflito" ${ }^{37}$. Embora se argumente por sua utilidade doutrinária militar, de fato a sobreênfase no ato conflitivo acaba produzindo um dilema - como se age contra “o conflito”? É evidente que fazer do conflito o inimigo se traduzirá em reconhecer determinados grupos, que tenham determinados comportamentos (por exemplo, a agressão) como sendo os "inimigos nesse momento".

Isso desloca o que é uma decisão política para as ROEs das forças no terreno, colocando para o comandante de uma patrulha, de um posto ou de uma guarnição a responsabilidade pela ponderação da oportunidade política de uma resposta, caso a caso, e sem o benefício do apoio a tomada de decisão, por exemplo, do Conselho de Segurança da ONU.

Isso parece ser uma forma de adiar o reconhecimento político de que determinados grupos são contrários à paz que se deseja manter. No terreno, consolidam-se decisões políticas locais que podem estar contribuindo, ou solapando, as metas da própria PKO. Evidencia-se, ainda, a possibilidade da manipulação da percepção das forças de paz, buscando usá-las como aliados inconscientes.

Os que argumentam que a identificação consistente de um grupo como adversário da paz que se quer manter é inadequado ${ }^{38}$ deixam sem resposta uma questão. Se as Forças de Paz no terreno não têm - nesses termos, não podem ter - nenhum critério para a sua ação, então a situação é muito grave. Passa-se a apostar numa solução praticamente espontânea do conflito, em que a ação das forças e as atividades da PKO contribuem de forma "equânime” (ou aleatória) para todos os lados, ou se entregam a manipulação pura e simples desse ou daquele grupo. O que se quer com a sua presença, então?

A questão da imparcialidade, mesmo dividida, não sobrevive ao confronto de seus limites lógicos. Assim que qualquer direção seja decidida, então até mesmo caracterização de que "o inimigo é o conflito" não impedirá que se chegue a uma identidade concreta para ele.

A discussão sobre a identidade do "inimigo" convida a que se atente para a identidade do "amigo", isto é, dos aliados locais. Uma forma explicitamente política de lidar com essa questão é a de inquirir sobre a composição da coalizão que empreende a PKO num dado território. Quais dos beligerantes, se é que algum, são "aliados”? 
Esse não é um termo vazio - os "aliados", reconhecidos tática ou formalmente, passam a ter um papel no processo de tomada de decisão das metas da PKO. Nesse caso, qual passa a ser o status dos demais, que não são reconhecidos como "aliados” (e não necessariamente são "inimigos”) e que, portanto, têm uma voz diferenciada na definição de tais metas? O desejo de que todos os beligerantes "sejam aliados" é ingênuo e, mesmo, se tomado como orientação, perigoso para os objetivos políticos da coalizão. Afinal, se isso fosse possível, não se teria uma PKO no território.

Seria surpreendente se tal pergunta pudesse ser respondida pela teoria. Esse impedimento a produzir uma resposta direta é o que a teoria da guerra nos levaria a esperar. A dinâmica de uma guerra é sempre circunstancial na realidade - leva em conta personalidades, razão, paixão, sorte. O contexto político em seu sentido amplo, tanto histórico quanto idiossincrático, combina-se com que seja a balança do poder dentro e fora do território.

Para os fins de consideração política de PKO, parece-me ser o caso de se ir mais além e afirmar a pertinência específica do equilíbrio de forças propriamente dito. Essa construção parece tão útil que é oportuno propor os elementos básicos de uma tipologia das PKO a partir dela.

\subsubsection{Uma tipologia das Operações de Manutenção da Paz}

Desde a perspectiva de que PKO são guerras de coalizão, argumento contra a utilidade de sua classificação como feita até o presente, seja pela natureza de suas metas, seja pela natureza de seus métodos. Ao invés disso, proponho os elementos iniciais de uma tipologia que leve em conta o contexto político em que as operações têm lugar.

As metas de PKO não servem como critério útil exatamente por sua convergência com relação ao objetivo de uma paz estável. Isso é inevitável porque toda PKO, toda a guerra, objetiva uma paz. Tentativas de dar conta dessa generalidade inescapável acabam produzindo situações polares: ou tentativas de classificação que nada dizem sobre suas categorias, ou, no pólo oposto, tipologias que acabam distinguindo operações individuais, produzindo uma pseudotipologia que não é mais do que o rol das operações concretamente realizadas.

O fracasso dessa abordagem determinou a disseminação de tipologias que buscam classificar as PKO em função de seu método, isto é, pela natureza da tarefa que se espera venham a desempenhar. O problema aqui é menos evidente, mas resulta do fato de que o prognóstico do método a ser utilizado não corresponde à sua constância na realidade. Seja qual for o recorte adotado, a premissa de que um método vigorará ao longo da PKO de forma suficiente para que ele a caracterize só se sustenta num número limitado de operações. Para além desses, é evidente que métodos só serão característicos de $\mathrm{PKO}$ conquanto correspondam à suas 
necessidades. A maioria das operações da década de 90 modificou seus métodos, ou foi caracterizada, em termos de seu mandato, pela liberdade na escolha do método. Os métodos de PKO, além disso, estão em constante evolução procedimental, tanto quanto sujeitos a dinâmicas circunstanciais. Qual o valor, então, de tipologias baseadas em métodos, diante desses problemas?

Num sentido muito pragmático, o que passa por uma classificação atual a Agenda para Paz e suas peace making, peacekeeping, peace building e peace enforcement - como que encapsulam o problema. Sua ênfase no termo paz em cada uma de suas categorias revela a sua redundância. $\mathrm{E}$ o fato de que se acabou por tomar o que se pretendia fosse uma tipologia como descritor de uma seqüência temporal possível para qualquer operação encerra um juízo final quanto à sua utilidade enquanto uma tentativa de classificação.

A clarificação da natureza de PKO como guerra de coalizão serve, portanto, para que se possa reconhecer a possibilidade de que a primazia do contexto político possa servir para a classificação consistente das operações de manutenção da paz (PKO) e como base para uma tipologia.

Assim, se poderia propor as bases de uma tipologia que distinguisse as PKO a partir de seu contexto político nos seguintes termos:

- operações diante de beligerantes quiescentes (que são ou desejam ser Estados diferentes);

- operações diante de beligerantes ainda ativos (que são ou desejam ser Estados diferentes);

- operações diante de beligerantes numa Guerra Civil (nas quais os beligerantes aspiram ao controle do Estado e desejam governar sobre os demais);

- operações diante de beligerantes que são senhores-da-guerra (e o Estado ou não existe ou é uma ficção legal).

Essa tipologia nada diz sobre a viabilidade intrínseca do empreendimento de uma PKO em qualquer das suas situações típicas, e nem poderia fazê-lo. Esse prognóstico depende de considerações adicionais, que dizem respeito à dialética de meios e fins em termos gerais, e a considerações táticas e estratégicas de PKO em termos específicos. Tendo apresentado algumas considerações sobre fins, iniciam-se as considerações sobre meios, por meio das considerações táticas em PKO.

\subsection{Considerações táticas em PKO}

O reconhecimento de que PKO são guerras permite que se aborde suas considerações táticas desde uma perspectiva teoricamente consistente. Essa 
consistência, por si mesma, dá conta de três problemas recorrentes na literatura: i) a tendência, nascida do equívoco de que a realidade é fracionável de forma simétrica às organizações, que resulta no erro de se atribuir o caráter tático a um determinado nível hierárquico ou dimensão organizacional ${ }^{39}$; ii) a tendência, nascida do equívoco de que PKO é alguma outra coisa que não a guerra, de se suprimir o conteúdo essencialmente combatente da tática e substituí-lo por elementos procedurais de relacionamento civil-militar ${ }^{40}$; iii) a relutância ou, até, a recusa, nascida do equívoco que se considerar que a paz só pode resultar de métodos pacíficos, de se tratar das perspectivas força-contra-força envolvendo forças de $\mathrm{paz}^{41}$.

A consideração de aspectos táticos corresponde a um recorte analítico do fenômeno bélico. Leva em conta as variáveis que se relacionam com o uso da força em combate. Esse entendimento desautoriza a que se queira subscrever que as considerações táticas pertencem, exclusivamente, a um determinado escalão hierárquico, ou a um determinado tamanho organizacional. Há considerações táticas em todo o fenômeno bélico, seja na ação de combatentes individuais, seja no conjunto de todas as forças armadas de que se dispõe.

A assunção de que existiria uma natureza específica e particular às operações de manutenção da paz (PKO), a seu turno, leva a que se considere que existiriam “considerações táticas de PKO”, distintas das considerações táticas elas mesmas. Assim, nomeia-se equivocadamente a consideração das necessidades e diretrizes procedimentais e de relacionamento civil-militar como sendo “táticas”. O resultado é simplesmente retórico, e resulta na confusão, inteiramente desnecessária, entre a sistematização das atividades políticas (relações públicas, por exemplo) e estratégicas (controle espacial, por exemplo) da força e as considerações de segurança propriamente ditas. Sendo PKO guerras, a questão simplesmente não se põe, e a distinção entre as ROEs da força e suas considerações táticas se restabelece.

Do momento em que se reconhece PKO como guerra, a perspectiva de que PKOs deveriam empregar apenas métodos pacíficos revela-se como sendo fruto de uma falácia mimética, que deseja atribuir às operações de manutenção da paz uma forma pacífica em harmonia - ética ou estética - com seus fins, a saber, a paz. Dessa forma, pode-se expor as ROEs extraordinariamente restritivas propostas e adotadas em algumas operações de paz pelo que são: um equívoco essencial sobre a natureza do que sejam as $\mathrm{PKO}^{42}$.

Como qualquer fenômeno bélico, o uso da força em PKO nunca produz resultados apenas táticos. Embora os resultados táticos de um determinado combate tenham conseqüências propriamente táticas - a tomada ou manutenção de uma determinada posição no terreno, por exemplo - eles nunca são os únicos resultados obtidos. Integrais ao fenômeno bélico, são interações de força-contra-força que têm conseqüências tanto políticas (tratadas mais acima) quanto estratégicas (tratadas mais abaixo). Como resultado, qualquer consideração de tática tem que levar em 
conta dois elementos principais: o das capacidades intrínsecas e possiblidades dos meios de força disponíveis (ou empregados) por cada um dos lados ${ }^{43}$ e o propósito do combate, expresso na missão combatente atribuída às forças e às regras de engajamento (ROEs) de sua ação $0^{44}$.

A consideração tática dos meios de força em PKO é, como seria de se esperar, a mesma que se faz para qualquer outra situação bélica. Resulta de um determinado arranjo de pessoas, materiais, equipamentos (especialmente, mas não exclusivamente, armamentos) e ambiente ${ }^{45}$. Existem diversas maneiras de exprimir os vários recortes analíticos e descritivos pelos quais se busca apreender o processo que determina uma determinada capacidade combatente. Um modelo útil é o "DTLOMS", que busca explicitar as componentes da Doutrina, Treinamento, Liderança, Organização, Materiais (inclusive equipamentos, armamentos, consumíveis) e do "Soldado", distinguindo as diversas formas pelas quais essas contribuem para a existência, incremento ou redução da capacidade de combate ${ }^{46}$.

Outra forma de expressar o mesmo processo de maneira mais abrangente é o de considerar o arranjo de armas combinadas que compõem as Forças de $\mathrm{Paz}$ (ou as forças que podem se opor a elas) que se deseje examinar ${ }^{47}$. Por armas combinadas compreende-se a forma pela qual os diferentes tipos de equipes, diversamente equipadas e preparadas, combinam-se para a produção de um máximo de capacidade combatente. A doutrina dos EUA, por exemplo, distingue três amplos tipos de armas em sua força terrestre: as armas combatentes (por exemplo, a infantaria ou a artilharia), as armas de apoio ao combate (por exemplo, a engenharia de combate ou a comunicação) e as armas de serviços de suporte ao combate (por exemplo, a logística ou o material bélico ${ }^{48}$.

Dada a ampla variedade atual de armas de combate, de apoio de combate e serviços de suporte ao combate; diante da variabilidade de arranjos organizacionais e doutrinários que atendem às funções destas armas nos diferentes Estados e em organizações irregulares; considerando os diferentes regimes de treinamento, prontidão e desempenho de determinadas unidades das forças; e apreciando a forma pela qual sistemas não combatentes podem atuar como multiplicadores da capacidade combatente, pode-se perceber que os diferentes contingentes militares que integram uma dada força de paz podem ter perfis e capacidades combatentes substancialmente diferentes. Além disso, política de defesa de cada país, as decisões e prioridades de projeto de força, e ainda os termos específicos de composição dos contingentes para uma dada PKO modificam a disponibilidade e capacidades específicas disponíveis para as forças de paz no terreno. Fatores análogos modificam as capacidades das forças que podem vir a se opor a elas.

A capacidade combatente resultante tem um papel inevitável no processo de tomada de decisão. Cada PKO individual terá que levar em conta as possibilidades de interação contraforças que um determinado conjunto de unidades permite no terreno, considerando as diferentes contribuições possíveis dos 
contingentes de cada Estado participante, antecipando ainda os arranjos e mecanismos capazes de levar em conta a evolução dessas contribuições em situações específicas. Como em qualquer guerra, as decisões sobre a composição da força baseadas em critérios estritamente políticos (a lógica política) precisam ser temperadas pela ponderação das exigências táticas dos enfrentamentos possíveis (a gramática dos meios).

Percebe-se então que existe um fator de risco na prática de compor as forças de paz por critérios principalmente políticos: por exemplo, optando por forças leves em função de seu menor custo ou pela percepção de que são menos 'ameaçadoras' (no limite, paradoxalmente, são forças menos fortes) ou, ainda, pela percepção de que determinado tipo de força sinaliza uma determinada medida de compromisso ou envolvimento com uma dada PKO. Embora essa seja uma decisão legítima, já que a composição da força é, de fato, uma decisão política, a questão é que se pode estar compondo uma resultante potencialmente ineficaz diante da realidade tática em que as forças serão chamadas a agir. Como resultado, pode-se colocar em risco o próprio objetivo político pretendido quando se decidiu pelo empreendimento de uma dada PKO.

Existem critérios do estado-de-técnica do emprego de força que devem ser considerados de forma a atender as demandas concebíveis da realidade tática em que a PKO terá lugar. Por exemplo, a posse de artilharia ou engenharia de combate, que tem um forte efeito multiplicador na eficácia combatente, é essencial para que a estimativa de efeito de uma dado efetivo corresponda às expectativas usuais.

A artilharia permite um apoio de fogos a grande distância e com grande responsividade, permitindo respaldo de todas as frações de tropas a seu alcance. Assim, potencialmente, cada grupo combatente pode dispor do poder de fogo de artilharia de toda a força no momento do combate.

A engenharia de combate, a seu turno, pode tanto viabilizar movimentos e instalações quanto estabelecer barreiras e demolir estruturas indesejáveis. Um corte, por exemplo, pode ser aberto pela engenharia de combate permitindo o acesso a uma região isolada; o mesmo corte pode ser demolido de forma completa e segura para assegurar o isolamento entre beligerantes.

O critério das armas combinadas do estado-da-técnica exemplifica um critério abrangente que busca assegurar que essas capacidades estarão disponíveis, quando necessárias. Forças despidas desse tipo de recurso podem induzir a percepção equivocada de suas capacidades, por um lado; e podem ser incapazes de atingir as metas táticas delas desejadas, por outro. O estado-da-técnica é uma salvaguarda intrínseca à natureza dos meios, que explicita e busca assegurar um desempenho satisfatório quando de seu emprego.

Há constrangimentos políticos explícitos e limites no emprego de meios que derivam diretamente de opções políticas. Esses têm lugar em qualquer guerra, e se tornam tão mais visíveis quanto mais afetem o desempenho ou a liberdade de 
ação tática das forças. Pode ser uma decisão política preferir, ou restringir, determinados métodos de emprego de força ou determinadas direções de ação, como parte de seu esforço para alcançar os objetivos políticos que busca. Regras de Engajamento (Rules of Engagement - ROEs) é a expressão concreta de tal interesse, e eles estão presentes em qualquer guerra.

O fato de que em algumas ocasiões as ROES enfatizam a aderência às exigências táticas que maximizam a destrutividade do emprego de forças contra o inimigo, ou são tolerantes com alternativas que podem maximizar o desempenho combatente da força às custas de dano colateral para vidas e propriedade, em nada diminui a sua presença ou constância. É apenas que nessas circunstâncias essas ROEs expressam o entendimento político de que essa destrutividade e esses danos colaterais não prejudicam os objetivos políticos pretendidos. Percebe-se assim que as ROEs variam, explícita ou tacitamente, com as circunstâncias. Para exemplificar com uma guerra na qual o assunto poderia parecer menos pertinente, a ROE das forças Aliadas na França em 1944-45 era menos tolerante de danos colaterais que a ROE dessas mesmas forças em operações na Alemanha para o mesmo período.

As capacidades intrínsecas, as demandas táticas e as ROES com as quais as forças de paz têm que lidar são resultado, portanto, de decisões políticas em sua composição e orientação, considerado o estado-da-técnica do uso da força. Esses elementos buscam assegurar que o uso das forças contra outras forças apóie a produção de uma estabilidade pacífica e auto-sustentável.

As considerações táticas, então, podem ser sumarizadas como servindo para informar a decisão política sobre os resultados que se podem produzir a partir de um determinado juízo sobre os métodos aceitáveis ou desejáveis. Fazer o contrário é arriscar-se a colocar forças de paz em situações taticamente insustentáveis, arriscando a estabelecer uma confusão contraproducente entre o objetivo político de seu emprego e os métodos autorizados para esse emprego. Isso conduz diretamente à necessidade de se considerar o uso dos usos de forças contra outras forças, é dizer, às considerações estratégicas.

\subsection{Considerações estratégicas e meios distintos dos de força em PKO}

A estratégia, entendida como o uso dos combates para os propósitos da política, diz respeito fundamentalmente ao equilíbrio de forças numa determinada área de operações. O propósito da estratégia de cada lado é utilizar-se dos combates de tal forma que esse equilíbrio se incline em favor dos objetivos políticos da guerra, sumariamente, de maneira que as perdas inimigas sejam mais que proporcionais às suas próprias. Note-se que a questão não se reduz nem a números relativos nem a uma proporção direta entre as perdas de cada lado. A questão é o equilíbrio de forças na área de operações, ele mesmo, até o ponto em que se obtenham condições 
em que o objetivo político tenha sido atingido. Esse é o cerne das metas bélicas que se deseja estabelecer a partir de uma perspectiva estratégica em busca de determinados objetivos políticos.

A questão é mais simples de ser entendida no caso de guerras ilimitadas. Nesse caso, o desequilíbrio de forças desejado é absoluto, já que só a completa subserviência, isto é, o completo desarme pela destruição de todas as forças inimigas, é capaz de obter os objetivos políticos pretendidos. Numa guerra ilimitada, a estratégia determina metas bélicas cujo resultado desejado é o do estabelecimento do monopólio da força na área de operações, em especial nas áreas que são as fontes das forças inimigas.

No caso de guerras limitadas, é bastante para obter tal uma situação em que as metas obtidas determinam a posse dos objetivos políticos pretendidos. Parte destas metas é a criação de uma situação tal em que eles possam ser defendidos contra as forças inimigas com expectativa de sucesso. Diante da impossibilidade de reverter o resultado pelo recurso às armas, está-se criada a situação em que a negociação de um acordo de paz é a alternativa lógica.

Como resultado, considerações estratégicas dizem respeito aos aspectos da situação que devem ser levados em conta em prol da produção de um desequilíbrio de forças favorável, identificando metas bélicas que o favoreçam, e que sustentem os objetivos políticos pretendidos. Isso se traduz na incorporação das dinâmicas políticas e táticas. Por um lado, no acompanhamento, e obediência, às prioridades e limites políticos que circunscrevem a escolha de metas bélicas e dos métodos utilizados para obtê-las. Por outro lado, na apreciação dos requisitos e possibilidades táticas disponíveis para as forças diante dos resultados particulares dos diversos combates. Só dessa forma, pode-se fazer uso dos enfrentamentos (de seus resultados) para o avanço dos objetivos políticos.

Isso equivale a dizer que nunca existirá uma estratégia única, ou padrão, passível de ser aplicada a toda e qualquer PKO. Cada PKO terá seus próprios contextos políticos e táticos, e uma evolução particular da situação.

Mais ainda, qualquer guerra, mas PKO em particular, inclui as alternativas de coerção e indução que são expressas por meios distintos que os de força. Assim, há que se admitir a possibilidade de que tais alternativas produzam a mudança de lado de algumas das partes, mudando o equilíbrio de forças.

Além disso, quaisquer iniciativas que resultem na expansão ou cerceamento da capacidade de criar, movimentar ou sustentar forças de cada uma das partes terá efeito similar. A existência dessas alternativas provê insumo adicional para considerações estratégicas, tanto em si mesmas quanto em termos de priorização de esforços combatentes necessários para o estabelecimento, proteção e defesa de tais iniciativas.

Como um experimento mental, imagina-se uma PKO na qual só existem duas facções: uma mais forte que a outra. Assume-se que a decisão política é tal 
que se apóia a facção mais fraca. A medida da força de paz necessária será aquela que permitir a essa facção obter um equilíbrio de forças na área de operações, embasando uma paz temporária.

Mas a construção de uma paz estável dependerá de toda sorte de iniciativas, capazes de consubstanciar definitivamente esse equilíbrio de forças. Será necessário empreender uma série de atividades que permitam à facção mais fraca equilibrar a superioridade da facção mais forte a partir de um certo momento de maneira auto-suficiente. Isso pode ter lugar de diversas maneiras. É irrelevante se isso se dará por adição à força do mais fraco, debilitando do mais forte; se pelo incremento da capacidade de criar e sustentar forças da facção mais fraca ou pela diminuição da mais forte. A questão é que qualquer uma destas mudanças objetiva o mesmo resultado final. $\mathrm{O}$ fato que a PKO determina o fortalecimento da facção mais fraca de forma permanente dá conseqüência estratégica a essas atividades.

A facção mais forte terá consciência desse desdobramento. A própria conduta estratégica por parte da força de paz depende da decisão da facção mais forte, que por sua vez leva em conta o resultado imediato sobre o equilíbrio de forças produzido pela chegada das forças de paz. Se a combinação das forças de paz e das forças da facção mais fraca é suficientemente forte, na situação tática da área de operações, para que a facção mais forte não vislumbre nenhuma possibilidade razoável de sucesso no recurso às armas, então o equilíbrio de forças já se modificou.

Diante dessa segunda situação, a facção mais forte terá diante de si uma escolha: se aceita esse resultado ou se resiste a ele. Se a facção mais forte está disposta aceitar esse resultado, então a PKO terá uma "solução pacífica”. No entanto, é possível que a facção mais forte não esteja disposta a aceitar essa situação de imediato. Se existe a possibilidade de que venha a aceitá-la, trata-se de uma guerra limitada, cuja solução dependerá da capacidade das forças de paz e da facção mais fraca impor perdas suficientes à facção mais forte. Se não, está-se diante de uma guerra ilimitada, em que só a submissão completa da facção mais forte pode produzir o objetivo político - a paz - que se deseja.

Se a combinação das forças de paz e das forças da facção mais fraca não é suficientemente forte, na situação tática da área de operações, para dar conta da margem de vantagem de forças da facção mais forte, então a expectativa é de que haja continuação das hostilidades que motivaram a PKO em primeiro lugar. Mais ainda, se as forças de paz não são fortes o bastante para anunciar uma mudança clara no equilíbrio de forças de imediato, ainda que explicitem como seu objetivo mudá-lo ao longo do tempo, será apenas um resultado esperado que a facção mais forte lute para tentar manter, no presente, o que vai perder, com certeza, no futuro.

Esse breve experimento serve para exemplificar que é precisamente porque o equilíbrio de forças (ou, mais amplamente, o equilíbrio de poder) em uma dada região não está evoluindo "naturalmente” na direção desejada que se lança mão 
de Missões (e Forças) de Paz. O objetivo político desejado de uma paz estável e auto-sustentável exclui a possibilidade da simples guarnição, por tempo indeterminado, por forças de paz.

Vê-se como forças de paz podem, sim, produzir um equilíbrio de forças temporário, que crie as condições para um arranjo entre as partes. Mas uma modificação no equilíbrio de forças em prazo mais longo exige uma mudança no equilíbrio de poder entre as facções, em particular, nas fontes de forças das facções. Como resultado, qualquer PKO terá que levar em conta, em sua estratégia, a extensão e natureza de iniciativas não combatentes, que buscam alterar esse equilíbrio, sob pena de ter diante de si uma demanda interminável por sua presença.

De uma maneira ou de outra, qualquer PKO está diretamente envolvida na determinação do equilíbrio de forças na área de operações. Conceber uma PKO em que isso não ocorre, ou determinar a prioristicamente que isso não deve ou não pode ocorrer, é conceber uma PKO inteiramente inócua, ou, visto de outra forma, condená-la ao fracasso completo.

Na direta razão de sua influência no equilíbrio de forças, ou seja, na contribuição em prol de uma situação pacífica, as PKO podem ganhar um papel crescente em termos do provimento da ordem pública, do respaldo às leis e da administração da justiça. Trata-se de um deslocamento inteiramente previsível, e que é tão mais pronunciado quanto mais as forças de paz correspondem a uma fração determinante do equilíbrio de forças numa dada região. Expressa exatamente a capacidade de uso de força que a PKO tem em seu cerne.

Já é comum que PKO tenham, como parte de seu mandato, a responsabilidade por essas atividades. Isso se dá principalmente por meio de organizações civis de polícia (civilian police - CIVPOL) - não confundir com a Polícia Civil do Brasil - ou pela reforma das organizações locais. Mas esse proviso recente não deve ocultar um fato importante: as PKO sempre tiveram a perspectiva de ter que lidar com essas atividades “da paz”, na medida em que elas eram julgadas deficientes ou, mesmo, quando não existiam. Percebe-se que as responsabilidades pelo provimento da ordem pública, pelo respaldo da lei e pela administração da justiça se imporão às forças de paz. Mais ainda, que essas responsabilidades serão tão mais impositivas quanto mais bem sucedidas sejam as atividades de produção da paz em relação a conflitos armados.

Mas essa é apenas a expressão mais visível - e mais formal - de tais responsabilidades. De fato, qualquer PKO tem atribuições com relação ao mandato do uso da força em prol da ordem pública, da lei e da justiça que se iniciam no momento mesmo de sua chegada a um dado território. Essas atribuições são intrínsecas à própria presença da PKO numa região, e sua urgência é inversamente proporcional à aceitabilidade (ou até à simples existência) dos arranjos policiais no território. Essa percepção embasa o tratamento das PKO desde a teoria de polícia, caracterizando-as como uma forma de policiamento multicultural, que se faz a seguir. 


\section{PKO incluem o policiamento multicultural ${ }^{49}$}

FLUELLEN: The perdition of th' athversary hath been very great, reasonable great: marry, for my part, I think the duke hath lost never a man, but one that is like to be executed for robbing a church, one Bardolph, if your majesty know the man; his face is all bubukles, and whelks, and knobs, and flames o' fire; and his lips blows at his nose, and it is like a coal of fire, sometimes plue and sometimes red; but his nose is executed and his fire's out.

KING HENRY V: We would have all such offenders so cut off: and we give express charge, that in our marches through the country, there be nothing compelled from the villages, nothing taken but paid for, none of the French upbraided or abused in disdainful language; for when lenity and cruelty play for a kingdom, the gentler gamester is the soonest winner.

Henry V, Ato II, Cena 6.

Para abordar as Operações de Manutenção da Paz (PKO) desde a perspectiva da teoria de polícia, propõe-se o seguinte. Faz-se uma breve apresentação da teoria de polícia de Bittner, explicitando o entendimento de que a razão de ser da polícia é o exercício do mandato do uso da força, qualificando-a como responsável pelo exercício desse mandato no Estado de Direito. A isso se segue o enquadramento das circunstâncias nas quais PKO assumem o mandato de uso de força, que pode ser caracterizado como uma forma de policiamento multicultural e, observadas algumas de suas particularidades, como um tipo de policiamento comunitário da alteridade.

\subsection{Teoria de polícia ${ }^{50}$}

Não há consenso sobre a existência de uma teoria paradigmática de polícia. Por um lado, os estudos policiais refletem uma situação paradoxal. A polícia é uma das agências governamentais mais conhecidas. É razoável esperar que a maioria das pessoas esteja ciente de sua existência e saiba como se relacionar com ela em caso de necessidade. Apesar disso, ela é também uma das menos conhecidas. O que a polícia faz de fato difere consideravelmente da maioria das expectativas e imagens de suas atividades.

Por outro lado, existe uma forte ênfase organizacional no respaldo da lei, na qual a qualificação técnica e o respeito aos direitos humanos tiveram um papel particular. Foi com essa ênfase que se conduziu o processo de profissionalização das organizações policiais nas últimas décadas. Esses foram os dois componentes principais de seu processo de modernização. E, no entanto, essa mesma ênfase mutilou a compreensão plena de seu verdadeiro mandato.

Compreende-se, assim, a difícil situação em que se encontram os estudos policiais. Vive-se de fato uma tensão insolúvel entre abordagens que querem reduzir 
a questão policial a seus aspectos jurisdicistas ou tecnicistas. Todo o problema reside no fato de que tanto uma quanto outra acabam por tomar a polícia não em si mesma, mas por suas condições de contorno. A perspectiva do que seja o estudo policial ele mesmo permaneceu, em larga medida, órfã.

Apesar disso, pouco seriam os que recusariam a oportunidade e o mérito de uma perspectiva teórica que buscasse enquadrar a polícia como um dos instrumentos coercitivos do Estado, e que identificasse, a partir daí, o seu mandato autorizativo. O ensaio de Bittner (1990b) atende a essa descrição.

Inicia-se pela distinção entre a natureza específica de polícia em tempos contemporâneos como distinto da governança civil do interior do Estado em todos os seus aspectos. Dá conta, assim, da origem e do uso do termo polícia nos termos dos século XVIII. Em seguida, trata a organização policial em geral, caracterizandoa como uma das várias organizações de regulação e coerção do Estado.

Nessa passagem, Bittner deixa passar - ousaria dizer que considera implícito - um ponto crucial. Trata-se de uma condição de possibilidade para a própria idéia de polícia como ele a expressa. Trata-se do fato de que a polícia, enquanto tal, só pode existir no contexto do Estado de Direito.

Sem essa ressalva, pode-se tomar equivocadamente a questão policial, confundindo-a com forças de ocupação do território e de repressão ao dissenso. A polícia é distinta de um corpo de tropa qualquer, que exerce sem restrição o controle do território ou da população. A idéia de polícia só faz sentido quando referida a um enquadramento particular, a saber, de um instrumento regulatório e coercitivo do Estado sob a Lei, ou seja, o Estado de Direito.

Desta perspectiva, pode-se tomar a estrutura Weberiana em que uma organização é caracterizada por uma regra ou norma que autoriza um determinado mandato; por uma forma de aplicação impessoal e universal; e por um padrão técnico de proficiência. Aceitos os dois últimos elementos como evidentes, podese então tratar da natureza autorizativa do mandato da polícia.

Dando conta da expectativa jurisdicista, Bittner demonstra que o mandato da polícia é distinto do respaldo da lei. Em primeiro lugar, não se pode esperar que a polícia seja chamada para respaldar todas as leis em todos os momentos. Conseqüentemente, o respaldo seletivo da lei é uma realidade intrínseca ao trabalho policial. Mais ainda, a polícia não age contra todas as violações da lei da mesma forma. Só atua diante de um subconjunto limitado das violações da lei. Encaminha a maioria das violações que lhe chegam a outras agências de execução da lei e coerção da infração. Assim, por exemplo, a polícia agirá imediatamente diante de um assalto. Mas encaminhará o tratamento de uma prática comercial irregular para outras agências.

Em segundo lugar, a polícia atuará, e se espera que ela atue, diante de uma ampla gama de circunstâncias em que "algo que não deveria estar acontecendo está acontecendo e alguém tem que fazer algo sobre isso agora”. 
Ou seja, a polícia tem que atuar diante da emergência. Assim, por exemplo, a polícia irá atender a uma parturiente, seja abrindo caminho para sua ida ao hospital, seja atuando como parteira ${ }^{51}$.

Desdobrando esse último ponto, a ação policial na maioria das ocasiões e invariavelmente em emergências não tem base numa apreciação legal. Nasce, ao contrário, de uma apreciação ad hoc e expediente pelo policial individual sobre a necessidade e decoro de sua intervenção. De facto, a polícia é uma organização única no aparato estatal. Apenas a polícia está autorizada a solicitar ou impor a obediência a uma solução transitória, imediata e expediente produzida por ela mesma. Nesse mister, não tolera nenhuma resistência, retardo, emenda ou oposição. Assim, o mandato autorizativo da polícia fica claro: o uso de força no Estado de Direito.

Essa breve exposição teórica clarifica como a provisão de serviços policiais se desdobra para além do respaldo à lei. Inclui bem mais do que isso. A polícia responde amplamente pelo provimento da ordem pública. Esse provimento admite, intrinsecamente, tanto o atendimento de segurança quanto o de assistência na emergência.

É essencial ir um pouco além de Bittner. É preciso destacar como a natureza do mandato policial restabelece os termos de seu relacionamento com a administração da justiça. A polícia só está parcialmente ligada a um sistema de justiça criminal. Mesmo essa ligação parcial é, em grande medida, condicional, sujeita ao juízo concreto e instantâneo do policial individual diante dos fatos.

A maior parte do trabalho concreto da polícia no provimento da ordem pública, e uma significativa parte de seu papel no respaldo à execução de lei, dispensa qualquer passo adicional em termos legais. Produz-se a obediência às leis tão-somente a partir da ação pronta da polícia e diante da perspectiva de que essa ação tenha lugar tão freqüentemente quanto necessário.

O efeito das penas que podem ser atribuídas pelos tribunais e juízes tem um papel relevante no funcionamento da polícia na sociedade. Mas, na realidade, só uma pequena percentagem das intervenções policiais resulta em enquadramento criminal, e uma percentagem ainda menor produz qualquer punição. A obediência voluntária de sanções e penalidades (por exemplo, multas) e o recurso a ações civis têm um papel muito mais destacado no provimento da ordem numa sociedade democrática. Isso tem lugar independentemente de uma ação policial concreta.

A longevidade e constância desses mecanismos não policiais do provimento da ordem ganham a força do hábito. A certeza da existência da polícia para respaldálos, isto é, o uso potencial da polícia, faz com que seja irracional desafiá-los. Chegase, assim, ao ponto em que a idéia da polícia (i.e., "Para com isso ou eu chamo a polícia”) se torna um fator preeminente na preservação da ordem pública numa sociedade. 
Tendo apresentado a teoria de polícia, explicitado sua subordinação ao Estado de Direito e clarificado sua afiliação parcial e condicional ao sistema de justiça criminal, pode-se agora passar para o tratamento das responsabilidades de PKO em relação ao mandato do uso de força. Isso permite identificar na PKO a natureza de uma forma multicultural de policiamento.

\subsection{PKO e o mandato do uso de força: policiamento multicultural ${ }^{52}$}

Os objetivos políticos de qualquer PKO exigem a produção de uma paz estável no território em que operam. Em função da aceitabilidade (ou até da existência) dos arranjos de provimento da ordem pública, do respaldo da lei e da administração da justiça nesses territórios, e ainda em função de seu sucesso na manutenção da paz contra grupos armados organizados, essas metas obrigam ao mandato do uso da força. Assim, qualquer PKO terá que determinar como dará conta destas responsabilidades. Há pelo menos três aspectos distintivos na tarefa policial de qualquer PKO.

Em primeiro lugar, será necessário decidir e implementar alguma medida de acordo entre as exigências de provimento da ordem pública, de respaldo da lei e de administração da justiça à luz dos entendimentos em vigor no território. Esses incluem os regramentos emanados da própria ONU, os que estão em exercício por cada uma das várias forças componentes da Força de Paz e os que se associam às várias populações afetadas. Isso se desdobra numa série de considerações e observações.

Será necessário determinar o tipo de relacionamento entre a Força de Paz e as organizações locais armadas, policiais ou não. Em particular, será necessário clarificar a precedência e os limites relacionados ao convívio entre as prescrições da ONU para suas forças e a orientação das organizações policiais no território. Isso demanda uma apreciação diferenciada em função da organização e disposição das diversas forças no território, bem como da jurisdição que se atribui a cada uma das autoridades políticas que por ela respondem. Em muitos casos, apenas a autoridade da ONU terá abrangência sobre todo o território, o que impõe ainda a cautela da eqüidade no tratamento com as diversas organizações policiais locais.

Será ainda necessário considerar a resultante desses dois primeiros aspectos sobre qualquer proposta de exercício da função policial por qualquer uma das partes. Isso tem lugar num contexto específico, que se associa ao fato de que os limites do mandato do Conselho de Segurança, que autoriza uma dada PKO, não a eximem de responsabilidades implícitas mais amplas. Nesse sentido, a amplitude intrínseca do mandato policial aplicada a PKO determina o mesmo espaço de discricionariedade que o mandato policial num Estado, sem necessariamente emprestar-lhe os atributos de obrigação de obediência de suas determinações para as forças e populações locais. 
As Forças de Paz operam inapelavelmente sob os constrangimentos gerais e determinações reguladoras da ONU. Qualquer consideração posterior de suas alternativas está submetida aos regulamentos e providências daquela organização. Isso determina que ajam conforme os princípios e regras da organização, entre eles a Declaração Universal de Direitos Humanos, e ainda um amplo e complexo conjunto de documentos específicos relativos à execução da lei, provimento da ordem pública, atendimentos em questões de segurança e assistência. É importante perceber que esses documentos não delegam às Forças de Paz a liberdade de ação da polícia; nem lhes franqueiam a administração da justiça, exceto para seu próprio pessoal.

As Forças de Paz têm que subordinar a sua ação policial às restrições políticas diferenciadas da ONU diante de cada Estado, facção ou grupo étnico. Isso significa que o caráter de universalidade, e até de impessoalidade, do serviço policial pode estar comprometido por objetivos políticos específicos. Assim, por exemplo, pode-se ter a situação em que se deve prestar assistência ou socorro a um grupo mas não a outro. Mais freqüentemente, existem determinações que constrangem o atendimento policial a regras de proporcionalidade política. Essa proporção reflete a distribuição geral das populações, mas raramente coincide com a distribuição da população numa dada localidade. Tem-se, assim, um limite politicamente determinado para questões concretas postas diante das Força de Paz no terreno.

Além disso, existem lacunas na estrutura regulatória da ONU com relação aos serviços policiais. Esses dizem respeito precisamente aos aspectos da realidade que não se encontram expressos em termos legais, isto é, a maior parte dos casos. Só recentemente, na esteira do Relatório Brahimi, tem-se alargado o escopo das expectativas explícitas da ação de Forças de Paz na tarefa policial.

Mais ainda, existe uma tensão substantiva entre o conteúdo político da ação autorizada e a intervenção pautada por critérios, por exemplo, dos direitos humanos. Para um exemplo incisivo, considere-se que a possibilidade de ação das forças da ONU diante do massacre em Rwanda era regulatoriamente inexistente, ainda que desde então se tenha a compreensão de que a sua ação era implicitamente obrigatória.

Além disso, Forças de Paz carregam consigo seus próprios quadros legais de ação policial. Esses diferem, em alguma medida, dos da ONU. Se existe um preparo - reconhecidamente insuficiente diante da magnitude dessa questão - dos componentes explicitamente policiais de uma $\mathrm{PKO}$, o mesmo não ocorre com as forças militares. Essas se vêm diante de questões propriamente policiais no exercício mais básico da guarda de um perímetro ou de uma patrulha. Realizam-se ações que acabam sendo pautadas mais pelas expectativas sociais dos países de origem e pelo código disciplinar específico de cada componente militar. 
Um ponto recorrente tem sido o da simples transposição, nestas circunstâncias, dos dispositivos associados a tarefas de ocupação/retaguarda ou, mais generosamente, a operações em solo pátrio. De fato, o desempenho superior que se identifica na ação de tropas conscritas em algumas missões de paz parece ser explicado precisamente pela ausência de um preparo específico para tarefas de ocupação. Confrontados com o problema concreto, atuam como se estivessem diante de concidadãos ${ }^{53}$. É uma medida da superficialidade dessa situação que nem se considere o envio de conscritos para situações em que esse despreparo possa ter conseqüências táticas.

Finalmente, as Forças de Paz não compartilham, necessariamente, as expectativas sociais e as tradições legais das populações do território em que apóiam. Mesmo arranjos regionais de PKO, por exemplo, na África, revelam diferenças substantivas e potencialmente danosas entre as expectativas do que seja certo pelas tropas de paz e pelos locais. Mas usualmente essa diferença é ainda mais marcada, seja em termos do enquadramento normativo de parte à parte, seja até em termos das convicções religiosas. A essas se acrescentam ainda os riscos de distinções identitárias exacerbadas, exatamente, pelo convívio passado de povos vizinhos. Independentemente do enorme desafio que essa distância pode trazer, é necessário dar conta das expectativas locais.

Esse foco nos termos do relacionamento entre as Forças de Paz e as organizações e populações locais não esgota o tema. Serve apenas como um enquadramento geral da questão. É perfeitamente possível qualificá-los em termos das dinâmicas associadas às diferentes agências que atuam num dado território, ou ainda, pelas organizações não-governamentais que ali estejam. Da mesma forma, existem dinâmicas adicionais entre modernidade e tradição, entre estabilidade e mudança, que incidem de maneira particular quando se trata de populações multiétnicas em territórios conflagrados. Essas considerações podem ter grande relevância, mas de fato apenas acrescentam ao problema, sem mudá-lo essencialmente.

Compreende-se, assim, que se caracterize a tarefa policial de PKO como sendo um tipo de policiamento multicultural. Mas é possível desdobrar esse primeiro ponto pela circunstância da ação das próprias Forças de Paz. A perspectiva de que as Forças de Paz sejam o respaldo da decisão final sobre o provimento da ordem pública existe implicitamente em sua própria presença. Distintamente das forças de outras facções, as Forças de Paz estão irremediavelmente subordinadas aos termos do acordo político expresso em seu mandato, qualquer que ele seja.

Mais ainda, o seu próprio papel determina um tipo de convívio transcomunitário, que necessariamente se coloca entre - ou em meio - às diferentes facções e populações. A isso se soma, finalmente, a questão da situação de infraestrutura e serviços que se pode esperar num território deflagrado. A intensidade e variedade das demandas por assistência e segurança nestas circunstâncias 
implicam num relacionamento particularmente próximo entre as Forças de Paz e as comunidades. Assim, desde esse ponto de vista, o policiamento em PKO teria ainda um caráter adicional, o de um tipo de policiamento comunitário da alteridade.

É preciso apreciar que essas considerações têm lugar no terreno independentemente dos termos específicos de um mandato. Aplicam-se, potencialmente, quando não concretamente, mesmo que as Forças de Paz estejam excluídas da tarefa policial, sejam designadas como observadores não-intervenientes ou até mesmo se todo o pessoal relacionado com a missão for considerado como sob um regime extraterritorial. Pode-se identificar mandatos em que o provimento da ordem pública está explicitamente fora da alçada das Forças de Paz - por exemplo, nas operações de paz de primeira geração, onde a tarefa é a da interposição entre Estados beligerantes quiescentes.

Essa é, evidentemente, uma decisão política. A questão se desloca para a viabilidade se tal posicionamento no terreno. De maneira geral, essa postura será tão mais viável quanto menor for a população da área de operações. Mas é preciso que se aprecie que o empenho de sua explicitação é, em si mesmo, expressão da expectativa das responsabilidades policiais implícitas das Forças de Paz.

Em segundo lugar, mesmo quanto as Forças de Paz não têm responsabilidades explícitas, é necessário que considerem as circunstâncias e que tenham que atender a expectativas implícitas. Essas responsabilidades resultam diretamente da fração do equilíbrio de forças que corresponda às Forças de Paz. Independem, portanto, da natureza ou alcance dos arranjos policiais vigentes dependem, antes, de sua aceitação enquanto tal pelas populações locais e da acessibilidade das Forças de Paz. Ao oferecer uma alternativa de força capaz de prover a ordem pública e executar justiça, as Forças de Paz têm diante de si uma responsabilidade intrínseca à sua própria presença.

Até mesmo quando não se pretende nada além da observação armada, é preciso perceber como o ato de observar em si mesmo insinua a possibilidade, e conseqüentemente a responsabilidade, de se determinar alguma ação de força em resposta ao observado. Independentemente do mandato de ação específico, é suficiente considerar o impacto da simples omissão diante de uma grave violação dos direitos humanos. Mais ainda, a experiência do policiamento em circunstâncias de PKO, expressa nas vinhetas de treinamento, sugere que assuntos bem menos claros e bem mais inescapáveis se colocarão diante das Forças de $\mathrm{Paz}^{54}$.

Em terceiro lugar, as responsabilidades das Forças de Paz pelo policiamento podem ser tomadas como secundárias diante da necessidade de operações combatentes concretas ou potenciais. Essa prioridade não se traduz na anulação do mandato do uso da força. Ao contrário, qualifica-o formalmente como associado ao controle de áreas de retaguarda. A inexistência de um regramento da ONU nesse particular autoriza a vigência dos procedimentos e regulamentos da própria 
Força de Paz, o que se traduz, por exemplo, na vigência do Código Uniforme de Justiça Militar.

Em todas as circunstâncias, portanto, a execução de uma PKO exige que se considere a forma de atendimento de suas responsabilidades perante o mandato do uso da força. Isso implica um determinado arranjo que reflete a existência (e aceitabilidade) de organizações de polícia locais. Determina, ainda, as iniciativas das Forças de Paz com relação à supervisão e até ao exercício do policiamento. O contexto multicultural intrínseco a uma PKO estabelece um contexto particular, ao qual se acrescenta, ainda, a questão do papel da PKO em termos de construção da paz (peace building).

A perspectiva de que as Forças de Paz atuem como instrumento ou suporte de construção da infra-estrutura material ou institucional de um dado território tem implicações diretas em seu exercício do mandato do uso da força. Por um lado, determina uma prioridade diferenciada em sua ação, orientando-a rumo ao suporte destas iniciativas em detrimento de outras atividades. Por outro lado, estabelece um determinado papel no relacionamento com as organizações policiais, quando existentes, bem como com a própria população.

De forma mais incisiva que no caso de organizações policiais nacionais, a tarefa da construção da paz reforça a utilidade de relacionamentos comunitários entre as Forças de Paz e as populações que ela atende. Do momento em que a questão policial se introduz nesse quadro, percebe-se a especificidade de um tipo de ação policial comunitária particular, em que os agentes policiais não compartilham, necessariamente, dos mesmos valores que a comunidade em que atuam. A perspectiva multicultural é, portanto, reforçada pela possibilidade de que os agentes policiais não compartilhem de vínculos culturais com nenhuma das comunidades em seu território. Isso determina a oportunidade de um enquadramento específico e distintivo, o de um policiamento comunitário da alteridade.

O ponto a ser destacado, como resultado, é que o policiamento comunitário multicultural não teve solução em nenhum dos diversos contextos em que ele se apresenta. Não se tem, ainda, um entendimento consolidado das formas de sua prática e muito menos de um enquadramento cognitivo mais abrangente. Ao contrário, o desafio do policiamento comunitário multicultural é uma das questões prementes em todas as democracias ${ }^{55}$.

As condições em que PKO têm lugar refletem mais do que apenas a questão policial, em termos do mandato de uso da força sob o Estado de Direito. Podem envolver a própria definição constitucional da natureza específica do Estado de Direito. Nesses casos, espelham a vontade de grupos diante de questões de tal importância que eles se dispõem a tomar de armas para defendê-las.

A tarefa da construção da paz envolve-se em aspectos da construção do Estado em que essas questões são o objeto mesmo do dissenso. Em particular, a construção do próprio aparato policial e dos mecanismos de respaldo da lei e 
execução da justiça pode colocar as PKO diante de questões políticas de primeira grandeza. Como resultado, pode ser realisticamente suficiente limitar a ação de PKO às soluções tentativas, transitórias e limitadas ao provimento da ordem pública.

A teoria de polícia delineia os elementos que dão estrutura e significado à forma pela qual os arranjos coercitivos do Estado se expressam no mandato do uso da força. A especificidade da PKO na construção da paz e no processo de construção do Estado se traduz numa tensão entre o exercício do mandato do uso de força em termos do provimento da ordem pública e o processo da definição do Estado de Direito, na forma do respaldo da lei (qual lei?) e da administração da justiça. O objetivo político de uma paz aceitável exige a construção de uma ordem pública e de uma forma de administração da justiça igualmente aceitáveis.

É precisamente porque o mandato político de qualquer PKO se dá sob os termos da Carta das Nações Unidas que essas questões não podem ser resolvidas de forma expediente, com base nas inclinações e preferências dos Estados-membros participantes ou do Conselho de Segurança - nem mesmo as da Assembléia Geral. Esse fato faz com que se veja com algum receio a perspectiva de que uma PKO venha a ter que responder, ou esteja envolvida, num processo que inclua a mudança dos hábitos, estruturas e instituições que venham a atender às demandas de justiça e cidadania de uma sociedade multicultural independente. Mais ainda, ignorar essa limitação em prol de um resultado de curto prazo pode se revelar disfuncional.

Não há nenhuma razão, teórica ou política, que afirme a certeza do sucesso de tal empreendimento quando da saída das Forças de Paz. Esse é um processo longo e delicado que se deu em tempos históricos onde ele teve lugar. Assim, a perspectiva de uma tal intervenção traz consigo uma medida de engenharia social. A simples explicitação de tal perspectiva anuncia uma polêmica intensa, e de difícil solução, sobre a natureza mesmo de uma dada PKO, notadamente no contexto de guerras civis ou de Estados falidos.

De fato, se realmente se espera que uma PKO dê conta da totalidade dos desafios da coerção estatal, do provimento de ordem pública até a administração da justiça, então é mais útil reconhecer seu caráter propriamente civilizatório. Esse reconhecimento parece inescapável quando se considera o desdobramento das atribuições das PKO com relação ao mandato do uso da força e até do estabelecimento dos mecanismos do Estado de Direito. Isso explica, por um lado, a relutância política em seu tratamento pleno. E determina, em contrapartida, uma prioridade reflexiva.

\section{Observações finais}

O exercício do enquadramento das PKO desde as perspectivas da teoria da guerra e da polícia revela-se um empreendimento frutífero. Essas observações buscam apenas delinear de forma sumária os resultados alcançados, indicando 
algumas direções que podem ser de alguma utilidade para o aprofundamento do que sejam os requisitos das Missões de Paz no futuro.

Em primeiro lugar, a assertiva de que PKO são guerra de coalizão é mais um reconhecimento do que fruto de uma construção mais sutil. Desdobra-se facilmente da simples aplicação da teoria da guerra ao fenômeno de PKO. Assentase sobre a afirmação de que PKO são atos de força para dobrar à vontade de outrem ao mandato do Conselho de Segurança. O sucesso ou fracasso nessa intenção não altera sua natureza.

Aceito esse enquadramento, então os desdobramentos políticos, táticos e estratégicos das PKO são elementares. A questão passa a ser das especificidades políticas, táticas e estratégicas de cada PKO em particular, à luz da expectativa de normalidade da guerra que a teoria estabelece. Ainda assim, o seu desdobramento como base para a proposição de uma tipologia que pode dar conta que qualquer PKO concebível merece alguma distinção, por se apresentar como uma contribuição oportuna e original na literatura. Desde esse ponto de vista, a ambição de se delinear um enquadramento teórico útil para a compreensão das PKO parece suficientemente atendida.

Em segundo lugar, o enquadramento de PKO desde a perspectiva do mandato do uso da força tem um resultado menos nítido. Do ponto de vista do exercício do mandato do uso da força sob o Estado de Direito, trata-se de aplicação que apresenta resultados análogos ao anterior.

O reconhecimento do conteúdo propriamente policial nas PKO, que deriva das forças de paz, parece mais uma questão de reconhecimento do que propriamente de descoberta. A própria responsabilidade intrínseca pelo provimento da ordem pública, e as diversas considerações que permitem tomar o seu mister como um tipo de policiamento comunitária de alteridade são desdobramentos elementares.

Compartilham, naturalmente, dos mesmos limites que os desdobramentos dessa teoria têm em termos gerais, quando aplicada ao contexto de um dado Estado ou sociedade. Mas, nesse sentido, oferecem igualmente uma oportunidade distintiva para o desenvolvimento de abordagens e entendimentos na situação extrema da alteridade.

Já do ponto de vista do processo de edificação das formas do próprio Estado de Direito, os resultados são mais limitados. Pode-se apenas apontar alguns dos pontos em que o exercício policial, que depende da existência de um Estado de Direito, é gravemente comprometido pela construção sincrônica das bases e mecanismos desse mesmo Estado de Direito.

Aqui a questão é mais complexa, pois exige uma reconfiguração politicamente delicada do caráter potencialmente civilizatório das PKO. A questão remete, de fato, à simples contradição entre discurso e prática da Carta das Nações Unidas, revelando alguns de seus limites enquanto um construto westphalianamente datado e limitado. A trajetória política é mais ampla do que os termos da própria 
Carta. Isso recoloca a questão em termos políticos e remete a um tipo de reflexão mais abrangente.

Ainda assim, o edifício teórico da polícia serve para orientar as expectativas de normalidade do emprego de forças no provimento da ordem pública, desvelando seus elementos e conseqüências intrínsecas, e acautelando contra formulações irrealistas seja dos termos dos mandatos, seja mesmo das ROEs e políticas de relacionamento com as populações locais.

Em terceiro lugar, pode-se tomar os argumentos apresentados como uma reafirmação da utilidade de paradigmas existentes, no sentido estrito da capacidade explicativa de paradgimas científicos diante de um novo fenômeno. Não se pode querer emprestar à teoria da polícia de Bittner, e muito menos ainda, à teoria da guerra de Clausewitz o brilho de uma novidade. E, no entanto, evidencia-se a existência de uma agenda não explorada de trabalho a partir tanto de uma quanto de outra.

A familiaridade com esses edifícios teóricos, em particular com o segundo, aproxima-se do que se poderia considerar como os requisitos do estado-da-literatura, tão obrigatórios quanto qualquer conhecimento pode ser considerado obrigatório. São itens com cujo conteúdo se poderia esperar um grau de familiaridade essencial a quaisquer esforços de maior fôlego nos campos dos estudos bélicos ou, até, policiais. Assim, parece uma admoestação pertinente perceber como elas puderam ser subtraídas das trajetórias de estudos de PKO. Isso sugere a utilidade de uma revisão análoga em outros campos de igual densidade de definições e arbítrios políticos e administrativos. E aponta, ainda, para a sempre oportuna discussão dos conteúdos e trajetórias curriculares que se referenciem aos temas bélicos ou policiais.

Finalmente, podem-se tomar as direções apontadas como referências de partida para o contraste com outras perspectivas concorrentes à luz da empiria. Pode-se, ainda, apoiar o exercício de comparação entre as perspectivas onusianas das PKO com as produzidas por forças armadas ou polícias, sem o apriorismo de sua completa incompatibilidade ou o veto de sua pertinência. Esses enquadramentos têm, portanto, ao menos a utilidade de induzir a contrastes pouco comuns entre o acervo das reflexões propriamente bélicas e as missões de paz, em torno da questão do uso de força; e de questões de relações internacionais e domésticas, em torno da questão do mandato do uso de força sob o Estado de Direito.

Outubro de 2002

\section{Notas}

1 Eu dirigiria o leitor a Rikhyie 1997 para uma história sincera das operações de manutenção da paz (PKO) desde seu início. Também é oportuno recorrer a Leentjes 1997 e, em particular, a Lorenz 1998 para um comentário pertinente de como políticas nacionais influenciam a atitude de um país diante do que seja PKO, modificando o conteúdo e as expectativas de PKO em 
função de suas metas próprias. Nota Bene que a questão não é a de julgar o valor ou a oportunidade dessa decisão, mas exemplificar a observação sobre a fragilidade de definições atuais diante da realidade da política internacional. Uma tentativa recente de dar forma ao que sejam as missões de paz desde o ponto de vista teórico e legal pode ser encontrada em Proença Jr 2002.

2 Por exemplo, veja-se Boutrous-Gahli $(1994,1995)$. Para uma pesquisa mais larga, o leitor é orientado a Fishel 1998a; Morrison, Fraser \& Kiras 1997, e Sharp 1995, Lindenmayer 1997. O site da Web da ONU, http://www.un.org tem uma ampla variedade de documentos e links. Esse artigo faz pouco uso do conteúdo do "Brahimi Report” (2000) ou da produção dele decorrente. Isso reflete meu juízo de que as considerações e propostas ali contidas não alteram a minha percepção da natureza essencial do problema. De interesse particular para essa discussão é o artigo de Galtung 1975, em que a estrutura conceitual do que veio a ser a Agenda para Paz foi apresentada pela primeira vez. São destaques nesse contraste a ausência do peace enforcement na estrutura proposta por Galtung, por um lado; e a colossal abrangência do conceito galtunguiano de peace building, por outro.

3 A questão pode ser colocada de forma muito simples. A autodefesa inclui, ou não, a autodefesa da missão?

Se por “autodefesa” das Forças de Paz aceita-se o uso da força em defesa do cumprimento da missão determinada pelo comando ou, mais amplamente, o uso da força contra uma ameaça ao cumprimento do Mandato do Conselho de Segurança, então fica impossível distinguir essa "autodefesa" do simples cumprimento das ordens em qualquer força armada.

Se, por outro lado, exclui-se a (auto)defesa do cumprimento da missão ou do Mandato de tal definição, acaba-se caracterizando PKO rigorosamente nos mesmos termos que a simples observação militar.

Noutro plano, é preciso inquirir sobre a validade da suposição que todos os atos de autodefesa serão necessariamente resposta a um "ataque direto". Na mesma linha, a suposição de que essa resposta seria levada a cabo de forma comedida. Em si mesmas, essas pareceriam ser uma proposta válida para caracterizar os critérios de autorização de uso de força em PKO. Argumentase que essa seria uma maneira de expressar o constrangimento específico e distintivo do uso de força de PKO. Mas é preciso caracterizar o que seja um "ataque direto”, por um lado; e o que o “comedimento” significa no contexto de uma ação continuada no tempo, por outro. Há problemas em ambos os termos.

Por exemplo, se por "ataque direto" entende-se exclusivamente a ação positiva do tiro contra Forças de Paz, isso tem conseqüências potencialmente desastrosas. Uma unidade não estaria autorizada a reagir enquanto fosse progressivamente bloqueada e cercada por grupos armados? Teria que permitir que o cerco se consumasse, e só poderia reagir quando recebesse fogo? Então não poderia ser - e cada vez mais seria, se adotada essa prática - tarde demais?

Por exemplo, uma perseguição bem conduzida poderia eliminar a recorrência de ataques por parte de um determinado grupo. O comedimento está em permitir a fuga desse grupo ou em empreender uma perseguição com rígido controle de fogo, priorizando a captura dos membros do grupo?

Esse tipo de questionamento precisa de um conjunto de constrangimentos de uso de força realistas e suficientemente informados. Esforços para descobrir uma solução desse dilemas ainda nos deixam numa área definitivamente cinzenta. Veja-se Daniel 1997 para uma revisão sucinta do assunto; para outra visão, veja-se Livermore 1997.

4 Tal descontentamento pode ser expresso de forma direta e franca por acadêmicos, por exemplo Fishel 1998b ou Dziedzic 1998; mas a chamada enfática em prol de resoluções claras, de unidade de esforços, e clareza no que sejam os limites do consentimento, entre outros temas, também é evidente em textos como, por exemplo, o pragmático Bonn \& Baker 2000. Veja-se, em particular, Manwaring \& Fishel 1998 para um resumo razoavelmente completo das "lições já deveriam ter sido aprendidas.” 
5 Um único caso de fracasso em peace enforcement autoriza, por si só, a invalidação do conceito e o abandono dessa alternativa? Veja-se Daniel 1997 para a apresentação da fragilidade de tal posição, e Betts 1995 para problemas estruturais na natureza de PKO como atualmente entendida. A posição do “Brahimi Report” (2000) é talvez a mais radical: a ONU deveria abrir mão de toda e qualquer missão que se caracterizasse como sendo de peace enforcement, delegandoa a “coalizões de voluntários”. A questão, claro, é para que então serviria o Capítulo VII da Carta das Nações Unidas.

6 Por diversos limites de acesso, tenho consciência de uma fração substancial da literatura a que não tive ainda acesso. Assim, se algum elemento do que se apresenta mais abaixo já foi dito em outro lugar, por outro autor, eu alegremente concedo a honra e muito apreciaria a indicação da referência.

7 Trabalho, já há algum tempo, na questão da atualidade e pertinência da Teoria da Guerra de Clausewitz, particularmente com Eugenio Diniz e Salvador Ghelfi Raza. Esse segue sendo um empreendimento profícuo e produtivo; uma seleção de passagens prévias desse esforço contínuo pode ser achada em Proença Jr \& Diniz 1998, 2001; e Proença Jr, Diniz \& Raza 1999. Para uma visão mais aprofundada do tema, veja-se Diniz 2002, inclusive para uma aplicação direta à teoria das relações internacionais; para uma discussão algo mais aprofundada do conteúdo da teoria Clausewitiziana, veja-se Diniz \& Proença Jr, (2002), no prelo.

8 Trabalho, já há algum tempo, na questão da atualidade e pertinência da Teoria de Polícia de Bittner, particularmente com Eugenio Diniz e Jacqueline Muniz. Uma amostra dos frutos de tal trabalho pode ser achada em Muniz, Proença Jr \& Diniz 2000.

9 Registro que, pelo menos depois do "Relatório Brahimi” (2000), a ONU parece tolerar o uso de Peace Operations como a categoria geral; parece, assim, ter se dado conta da impropriedade de se designar tanto o conjunto de todos os tipos de operações quanto um tipo específico pelo mesmo termo, a saber, “operações de manutenção da paz” (PKO). Apesar disso, esse segue sendo o nome internacional para o conjunto das operações de paz, e de fato, mesmo após a implementação inicial do Relatório, segue sendo o nome do Departamento de Operações (de Manutenção) da Paz. Eu respeito o uso do termo “operações de manutenção da paz” (PKO) nesse contexto, inclusive em termos de compatibilidade de sua abreviatura em inglês, embora prefira o termo "Missões de Paz" como categoria geral.

10 Reconheço o débito com os alunos e ouvintes da disciplina "Projeto de Força” de 1997 pelo o estímulo que provocou a clara categorização da crise como um caso de guerra limitada, em particular a Salvador Ghelfi Raza. Eu argüiria que há algo para ser aprendido sobre o desenvolvimento paralelo do tema da "administração de crises” (crisis management) e do tema das Missões de Paz ou “operações de manutenção da paz” (PKO). Aqui desejo apontar como tanto um quanto outro tema foram apresentados, ou ao menos percebidos, como sendo objetos únicos e distintivos, só tratáveis por estatuto teórico próprio. Argumento nesse artigo que esse não é tampouco o caso para PKO.

11 Embora existam os que afirmam que as PKO são uma forma de paz. Para um panorama abrangente dessa posição, veja-se Featherstone 1994. Trata-se de uma posicionamento político, e até militante, mas que tem força nos estudos de paz. Parece-me bastante evidente que se houvesse paz num dado território, as forças de paz não teriam o que fazer lá.

12 A opção do anglicismo compelir (de to compel) é uma escolha necessária, dada a carga valorativa associada a "coagir” (que insinua uma assimetria, o que não é o caso e que, de fato, contamina a definição); o desuso de “compulsar” (como em compulsão, que no uso do idioma atual insinua motivações intrínsecas de quem age, que é contraditório com o que se quer dizer); a dualidade de “constranger" (que insinua uma medida de embaraço, distante do que se afirma aqui, que é o efeito deliberado do ato de força ele mesmo) ou, mesmo, a derivação jurisdicista de "obrigar” (que poderia ser uma alternativa, mas que dada a força de seu uso na terminologia legal, insinua 
um juízo positivo do que se deve fazer, “por obrigação”). Em Proença Jr \& Diniz (2002) esperamos dar conta dessa e de outras decisões de tradução de forma mais extensa.

13 Clausewitz 1993: 83.

14 Esse é um caso realmente freqüente nas ciências. A termodinâmica, para citar um exemplo imediato, não tem conceito para "frio"; o frio é simplesmente expressão de uma ausência de calor. Nesse sentido, a insatisfação de Galtung 1976 com a definição "negativa” de paz me parece, no mínimo, inapropriada. Remeto o leitor às excelentes críticas de Boulding 1977.

15 Novamente, o caso da "administração de crises” pode servir para iluminar a forma específica com a qual o tema é tratado em Boutrous-Gahli 1994, 1995 em contraste, por exemplo, com Bonn \& Baker 2000.

16 Eu adotei aqui uma abordagem assumidamente minimalista, suficiente para as necessidades argumentativas de um artigo. Talvez seja o caso de uma revisão mais abrangente numa outra ocasião.

17 Aqui também decidi-me por uma abordagem suficiente, empregando uma perspectiva algo impressionista a partir de fontes secundárias. Para um contato com essas fontes, eu identificaria Fishel 1998a, Barrasch 1990 e Detter 2001 para os que se interessem por essa percepção de “trajetórias” aplicada a PKO.

18 Reconheço o débito para com Clóvis Brigagão por suas observações lúcidas sobre a importância e percepção desse componente da trajetória de PKO.

19 Veja-se, por exemplo, Proceedings 21.

20 Reconheço o débito para com John Fishel no que diz respeito à questão da distância entre a forma (para)acadêmica de diversos dos documentos normativos das forças armadas dos EUA e seu conteúdo propriamente militar ou administrativo. Em particular, seus exemplos dos momentos críticos da escritura dos primeiros manuais de OOTW foram de grande importância para minha compreensão da multiplicidade de pressões a que seus autores estão sujeitos, e o caráter expediente de diversas decisões cuja redação faz com que aparentem mais solidez do que de fato possuem.

21 Um excelente exemplo de um tal fio é o do trajeto do "Paradigma Manwaring”, que se desenvolveu desde o modelo SWORD durante os anos 80 e 90. Para um histórico desse paradgima, veja-se Fishel 1998b; para uma síntese do estado-da-literatura, veja-se Last 1998.

22 Custa-me crer que se precise de evidência mais incisiva do alcance desses esforços do que a adição do item “Considerações Civis” ao secular "missão-inimigo-tempo-terreno-tropas” da tomada de decisão militar pelo Exército dos EUA. Veja-se Bonn \& Baker 2000, ou o site do Exército dos EUA - http://www.army.mil para o “Manual de Campo 100-5, Operações” (FM-100-5, Operations) a base doutrinária de toda sua concepção de guerra, e ainda o "Manual de Campo 100-23, Operações de Paz” (FM 100-23, Peace Operations). A discussão do significado da concepção de forças de "amplo espectro" como o arrimo conceitual do projeto de força dos EUA no século XXI tem implicações não triviais, seja para a discussão de PKO, seja mesmo para a discussão da política de defesa de qualquer país.

23 Veja-se, para um panorama desses resultados Barrasch 1990; para um sumário de alguns dos principais dilemas, veja-se Last 1997.

24 Clausewitz 1993: 83.

25 Reconheço o débito que tenho com Paul K. Davis pelas perguntas que me levaram a enfocar o assunto como talvez eu não viesse a fazê-lo. Qualquer estudioso da guerra tem uma dívida eterna para a viúva de Clausewitz, Marie, sem cujos esforços Da Guerra provavelmente nunca teria sido publicado. Para o leitor, eu indicaria, até a disponibilização da nova edição do Da Guerra, em preparação para 2002, Clausewitz 1993, com uma nota particular para os ensaios contidos nessa edição. Chamo particular atenção para o valor e a qualidade do conteúdo de Corbett 1988. A home page de Clausewitz, mantida por Christopher Bassford, é uma magnífica primeira referência para os que tenham algum interesse em Clausewitz. http://www.clausewitz.com 
26 Carecemos de um apanhado sistemático da evolução do pensamento sobre a guerra contrastado com a prática. Para o período desde a Renascença, as duas coletâneas Earle 1943, Paret 1986 são adequadas; uma revisão mais sintética pode ser encontrara em Elting 1974. Com seus diversos problemas de atualização, a obra magna novecentista de Delbrück (1971, 1972, 1973, 1974) segue sendo a fonte primeira e de maior fôlego para a discussão do que se denominava, quando de seus escritos, como “a arte da guerra” ao longo da história. Os leitores são advertidos que muito da crítica contemporânea dirijida à obra de Delbrück deriva de ressalvas revisionistas quanto à sua postura estritamente materialista, e não a erros de fato ou incorreções.

27 Apesar da prevalência de seu uso (por exemplo, nas escolas militares), vi-me agradavelmente surpreso pela ausência de qualquer defesa do espectro dos conflitos como um arcabouço conceitual na literatura. Isso pode ser uma falha em minha revisão bibliográfica, e apreciaria a referência, se existe, de tal defesa. Para uma apresentação introdutória suficiente do que seja esse gráfico, sugere-se Griess 1986.

A estrutura conceitual clausewitiziana permite criticar consistentemente outras práticas de redefinição de guerra por critérios quantitativos (taxa de mortos por período, por exemplo), por critérios jurisdicistas (só há guerra se há declaração de guerra) e outros. Essas outras abordagens, ainda que danosas ao entendimento, têm relativamente menos presença no tema dos estudos de PKO e, em favor da concisão, podem esperar outra ocasião.

28 A compreensão de que política, estratégia e tática são dimensões onipresentes no fenômeno bélico desautoriza sua dissolução em adesão às estruturas hierárquicas das forças em "níveis" da guerra. Esse equívoco admite crítica análoga à que se fez à questão da "intensidade” da guerra, mas infelizmente é algo mais longa. Excuso-me de fazê-la aqui em detalhe. Dado o caráter sedutor que esse erro tem - ao atribuir a política ao chefe do Executivo, a tática ao tenente e a estratégia ao general, para ser sucinto - esse tema merece tratamento, a ser apresentado noutra ocasião.

29 Aqui é importante não confundir a legalidade dessa decisão, dada a obrigação de obediência de todos os Estados-Membros às decisões emanadas do Conselho de Segurança nos termos da Carta da ONU com o amplo debate sobre a propriedade, legitimidade ou continuada utilidade de tais arranjos. Veja-se o artigo 25 da Carta, onde se lê: “Os membros das Nações Unidas concordam em aceitar e fazer cumprir as decisões do Conselho de Segurança de acordo com os termos dessa Carta.” Para um panorama do funcionamento da ONU, veja-se os diversos documentos de informação da própria ONU, em http://www.un.org.

30 Veja-se, por exemplo, Findley 1997. A expectativa, especialmente militar, de uma unidade política de ação em perfeita contrapartida com a unidade de comando da organização militar é fonte de diversas situações e mal entendidos ao longo de toda a estrutura de PKO. Desde o ponto de vista aqui apresentado, reflete apenas um entendimento ingênuo do que seja a política. Veja-se, por exemplo, o prefácio político de Wider Peacekeeping.

31 Veja-se, ainda, Wiseman 1997.

32 Confesso que ainda não estou satisfeito com esse tratamento da questão do consentimento em PKO. Para uma apreciação aprofundada do problema e uma exposição cândida dos impasses a que ele leva, veja-se Featherston 1994. Trato do tema explicitamente em Proença Jr 2002.

33 Teria se perguntado a Alexandre, o Grande (299-334 A.C.), em seu leito de morte, a quem deixava o seu Império. Com seu último alento, ele teria sussurado: "ao mais forte”.

34 Abordo explicitamente essa questão em Proença Jr 2002.

35 Veja-se Wider Peacekeeping e, de forma mais extensa, Morrison 1998.

36 Esse me parece o ponto de maior divergência entre Galtung 1976 e Boutrous-Gahli 1994, 1995. Galtung claramente espera que os “bons ofícios” tenham o caráter de uma forma de mediação, em que os lados em disputa se comprometam, de alguma forma, com um resultado concreto. A firme distinção da prática diplomática entre mediação e "bons ofícios” impediu que esse entendimento estivesse presente no Agenda para Paz; poderia se argumentar que isso fez de 
peace making um termo vazio de significado próprio. Nesse sentido, pode-se pensar que a concepção de peace enforcement realmente não pertenceria à $\mathrm{PKO}$, pelos motivos apontados por Galtung. Esse artigo resolve essa questão, ao eliminar a falsa impressão de que PKO seria um fenômeno único, distinto da guerra e da paz.

37 Veja-se, uma vez mais, Wider Peacekeeping e Morrison 1998.

38 Veja-se Wiseman 1997 e a discussão dos capítulos de concepções ‘operacionais’ e ‘estratégicas' Wider Peacekeeping.

39 A questão dos alegados níveis da guerra é um problema atual, já que é tema recorrente na literatura militar. Não existe, realmente, uma defesa teórica de sua existência. Numa prática muito comum em textos militares, eles 'simplesmente existem'. Veja-se a tentativa de Griess 1986 de emprestar alguma lógica ao que ele mesmo destaca como simples expediente. Esse é um tema que merece algum trabalho mais explícito.

40 Esses corresponderiam a procedimentos padrão não bélicos. Veja-se Morrison 1998.

41 A relutância dos proponentes de tal abordagem tem uma curiosa contraparte no entusiasmo militar pela garantia de que uma missão só exigirá métodos pacíficos. Trata-se de uma convergência de pólos opostos; os primeiros (por exemplo, Featherston 1994) dizem que não deve haver combate. Os segundos esperam que não haja combate (veja-se Boon \& Baker 1999 ou Wider Peacekeeping). Constrói-se então um falso consenso da expectativa de que o combate não tem lugar em PKO. Quando ele ocorre, assume-se, arrogantemente, que a "realidade está em erro."

42 O Relatório Brahimi argumenta por esse ponto por motivações estritamente pragmáticas, isto é, a impossibilidade de se produzir coação ou constrangimento sem o respaldo do uso da força. http://www.un.org/dpko.

43 É precisamente a especificidade dos meios de força em termos de seus requisitos e possibilidades que determina limites à ação bélica. É disso que se trata quando se fala da "gramática” dos meios de força: há coisas que são militarmente impossíveis ou, alternativamente, temerárias.

A questão da capacidade intríseca dos armamentos ("técnica") e a capacidade concreta de combate por grupos armados no terreno ("tática”) marca uma divisória importante. no primeiro caso, trata-se de uma discussão de engenharia de armamentos; no segundo, de Estudos Estratégicos. Note-se que desse ponto de vista, a discussão técnica da engenharia de armamentos não pertence, em si mesma, aos Estudos Estratégicos, embora possa ter significado quando altera elementos táticos. É precisamente a relação entre a discussão técnica da engenharia de bisturis e a Medicina - só se torna pertinente ao permitir ou restringir determinado procedimento cirúrgico. Veja-se Proença Jr, Diniz \& Raza 1999.

44 Para um aprofundamento dessa dinâmica e sua utilidade para uma modelagem consistente do combate, veja-se Gomes \& Proença Jr 2001.

45 Essa percepção, adotada pelo Grupo de Estudos Estratégicos, filia-se ao enquadramento geral da Engenharia de Produção. Para um aprofundamento, veja-se Proença Jr, Muniz \& Diniz 1996. Trata o contéudo dos processos pelos quais a atividade militar produz capacidade de combate como um tipo de trabalho, passível de estudo e análise em si mesmo. Para uma construção que chega a resultados de interesse desde um ponto de partida bastante diverso, veja-se Ancona 1989a,b,c. Em particular, para uma expressão do mesmo resultado sem, lamentavelmente, o desdobramento de suas conseqüências, Ancona 1989b (: 365-366); ver ainda (: 371).

46 Para uma discussão mais extensa, veja-se Gomes 2001.

47 Para um panorama da evolução das armas combinadas no século veja-se House 2001.

48 Para a exposição doutrinária do Exército dos EUA, veja-se FM 100-5 Operations; veja-se, para uma exposição introdutória, Griess 1986.

49 Há uma percepção crescente da importância do provimento da ordem pública, do respaldo legítimo da força ao cumprimento da lei e da administração da justiça no contexto das "operações de manutenção da paz”. Isso toma a forma das discussões da “Polícia Civil” (Civilian Police CIVPOL; não confundir com a polícia civil brasileira) como componente essencial de qualquer 
atividade de PKO. Para uma avaliação ampla e sistemática, veja-se Oakley, Dziedizc e Goldberg 1998; em particular, o leitor é dirigido a Rodriguez 1998, um Q\&A com o Chefe da Polícia de Chicago Matt Rodriguez e, para um sumário oportuno, para Oakley \& Dziedzic (1998) Conclusões.

50 Compartilho o trabalho rumo ao entendimento atual de uma teoria de polícia com Jacqueline Muniz, embora a formulação particular que expresso aqui tenha se desenvolvido na ausência de suas valiosas contribuições. Eu dirigiria o leitor a Bittner 1990a,b.

51 Bittner 1990b: 251.

52 Eu dirigiria o leitor a Dziedzic 1998, Kelly 1998 e Findely 1997; os desafios multiculturais de trabalho policial, e o diagnóstico claro dos limites para soluções e abordagens existentes pode ser achada em Shusta et al. 1995.

53 Tripodi 2001 apresenta o caso de forma clara e incisiva.

54 Veja-se, por exemplo, o conteúdo do CD de treinamento da própria ONU, disponível on line. http://<www.un.org/dpko>>

55 Para um diagnóstico otimista, veja-se Shusta et al. 1995. Veja-se, em particular, o contraste entre as experiências da Califórnia em relação ao restante dos EUA.

\section{Bibliografia}

ANCONA, Clemente. Armas. Enciclopédia Einaudi. Vol 14: Guerra-Estado. Lisboa, Casa da Moeda, 1989a, p. 330-347.

ANCONA, Clemente. Guerra. Enciclopédia Einaudi. Vol 14: Guerra-Estado. Lisboa, Casa da Moeda, 1989b, p. 348-371.

ANCONA, Clemente. Táctica/Estratégia. Enciclopédia Einaudi. Vol 14: Guerra-Estado. Lisboa, Casa da Moeda, 1989c, p. 372-396.

BARRASCH, David A. An Introduction to Peace Studies. Cambridge: Cambridge University Press, 1990.

BETTS, Richard K. The Delusion of Impartial Intervention. In SHARP, Walter Gary, Sr. (ed.) UN Peace Operations: a collection of primary documents and readings governing the conduct of multilateral peace operations. New York, American Heritage/Custom Publishing Group, 1995, p. 472-482.

BITTNER, Egon. The Functions of Police in Modern Society: a review of background factors, current practices, and possible role models. In: BITTNER, Egon. Aspects of Police Work. Boston: Northeastern University Press, 1990a, p. 233-268.

BITTNER, Egon. Florence Nightingale in pursuit of Willie Sutton: a theory of the police. In: BITTNER, Egon.. Aspects of Police Work. Boston: Northeastern University Press, 1990b, p. 233-268.

BOON, Keith E \& BAKER, Anthony E. Guide to Military Operations Other Than War. Mechanicsburg: Stackpole, 2000.

BOULDING, K. Twelve friendly quarrels with Johan Galtung. In: Journal of Peace Research.14 (1), 1997, p. 75-86.

BOUTROUS-GAHLI, Boutrous. An Agenda for Peace. New York: United Nations.

BOUTROUS-GAHLI, Boutrous. Supplement to an Agenda for Peace. New York: United Nations.

BRAHIMI REPORT. Report on the Panel on United Nations Peace Operations. New York: UN. (http://www.un.org/peace/reports/peace_operations/)

CLAUSEWITZ, Carl von. On War. New York: Alfred A. Knopf, 1993.

CORBETT, Julian S. Some principles of maritime strategy. Annapolis: Naval Institute Press.

DANIEL, Donald CF. Wandering out of the void? Conceptualizing practicable Peace Enforcement. In: MORRISON, Alex; FRASER, Douglas F; KIRAS, James. (eds.). Peacekeeping with 
muscle: the use of force in international conflict resolution. Clemensport: Canadian Peacekeeping Press, 1997, p. 1-16.

DELBRÜCK, Hans. History of the Art of War. (vols I-IV, various editions). University of Nebraska Press, 1974.

DETTER, Ingrid. The Law of War. Cambridge: Cambridge University Press, $2^{\text {nd }}$ Ed, 2001.

DINIZ, Eugenio. A Teoria do Balanço Ataque-Defesa, Clausewitz e a Teoria das Relações Internacionais. 2002. 270 p. Tese (Doutorado) - GEE-PEP-COPPE/UFRJ, Rio de Janeiro.

DZIEDZIC, Michael. Introduction. In: OAKLEY, Robert B; DZIEDZIC, Michael J \& GOLDBERG, Eliot M (eds.). Policing the New World Disorder: peace operations and public security. Washington, National Defense University Press. 1998. p. 3-18.

EARLE, Edward Mead (ed.). Makers of Modern Strategy. Princeton, Princeton University Press, 1943.

ELTING, John. The Superstrategists. New York, Stackpole, 1974 .

FINDLEY, Terry. Keeping the Peace: the tough parts. In: MORRISON, Alex; FRASER, Douglas F \& KIRAS, James. (eds.). Peacekeeping with muscle: the use of force in international conflict resolution. Clemensport: Canadian Peacekeeping Press, 1997, p. 161-166.

FISHEL, John T (ed.). The Savage Wars of Peace: toward a new paradigm of peace operations. Boulder, Westview, 1998a.

FISHEL, John T (ed.). War by other means? The Paradigm and its Applications to Peace Operations. In: The Savage Wars of Peace: toward a new paradigm of peace operations. Boulder, Westview, 1998b, p. 3-17.

FOLEY, David W. Appendix A: Remarks by Chicago Police superintendent Matt Rodriguez. In: OAKLEY, Robert B; DZIEDZIC, Michael J \& GOLDBERG, Eliot M (eds.). Policing the New World Disorder: peace operations and public security. Washington: National Defense University Press, 1998, p. 547-552.

GALTUNG, J. Essays in peace research. Copenhagen: Christian Ejlers, 1975

GALTUNG, J. Three approaches to peace: peacekeeping, peacemaking and peacebuilding. In: Galtung, J. (ed.). Peace, War and Defense: essays in peace research. Vol. 3. Copenhagen: Christian Ejlers, 1976.

GOMES, Mauro GF Mosqueira. Método para Mensuração de Desempenho de Unidades da Força Terrestre. 2001. Tese (Doutorado) - GEE-COPPE/UFRJ, Rio de Janeiro.

GOMES, Mauro GF Mosqueira \& PROENÇA Jr, Domício. Tactical Performance Evaluation, a conceptual framework. Journal of the International Test and Evaluation Association. September/October, 2001, p 16-24.

GRIESS, Thomas. Definitions and Doctrine of the Military Art. New York: Avery Press, 1986.

KELLY, Michael J. Legitimacy and the Public Security Function. In: OAKLEY, Robert B; DZIEDZIC, Michael J \& GOLDBERG, Eliot M (eds.). Policing the New World Disorder: peace operations and public security. Washington: National Defense University Press. 1998, p. 399-432.

LAST, David M. Theory, Doctrine and Practice of Conflict De-escalation in Peacekeeping Operations. Clemensport: Canadian Peacekeeping Press. 1997.

LAST, David M. Winning the Savage Wars of Peace: what the Manwaring Paradigm tells us. In: FISHEL, John T (ed.). The Savage Wars of Peace: toward a new paradigm of peace operations. Boulder, Westview, 1998, p. 211-239.

LEENTJES, Peter. Doctrine and Future Doctrine. In: MORRISON, Alex; FRASER, Douglas F \& KIRAS, James (eds.). Peacekeeping with muscle: the use of force in international conflict resolution. Clemensport: Canadian Peacekeeping Press, 1997, p. 153-160.

LINDENMAYER, Elisabeth. The United Nations and the Collective Use of Force: wither or whether?. In: MORRISON, Alex; FRASER, Douglas F \& KIRAS, James (eds.). Peacekeeping with muscle: the use of force in international conflict resolution. Clemensport: Canadian Peacekeeping Press, 1997, p. 173-176. 
LIVERMORE, Daniel. Peacekeeping and the use of force. In: MORRISON, Alex; FRASER, Douglas F \& KIRAS, James (eds.). Peacekeeping with muscle: the use of force in international conflict resolution. Clemensport: Canadian Peacekeeping Press, 1997, p. 167-172.

LORENZ, FM. Response: the US perspective of Operation Restore Hope. In: OAKLEY, Robert B; DZIEDZIC, Michael J \& GOLDBERG, Eliot M (eds.). Policing the New World Disorder: peace operations and public security. Washington: National Defense University Press, 1998, p. 433-436.

MANWARING, Max G \& FISHEL, Kimbra L. Lessons that should have been learned: toward a Theory of Engagement for The Savage Wars of Peace. In: FISHEL, John T (ed.). The Savage Wars of Peace: toward a new paradigm of peace operations. Boulder, Westview, 1998, p. $197-210$.

MORRISON, Alex. New Peacekeeping Partnership. Clemensport: Canadian Peacekeeping Press, 1998.

MORRISON, Alex; FRASER, Douglas F \& KIRAS, James (eds.). Peacekeeping with muscle: the use of force in international conflict resolution. Clemensport: Canadian Peacekeeping Press, 1997.

MUNIZ, Jacqueline; PROENÇA Jr, Domício \& DINIZ, Eugenio. Uso de Força e Ostensividade. In: Boletim de Conjuntura Política. Belo Horizonte: Departamento de Ciência Política, Universidade Federal de Minas Gerais, junho de 2000.

OAKLEY, Robert B \& DZIEDZIC, Michael. Conclusions. In: OAKLEY, Robert B; DZIEDZIC, Michael J \& GOLDBERG, Eliot M (eds.). Policing the New World Disorder: peace operations and public security. Washington: National Defense University Press, 1998, p. 509-536.

OAKLEY, Robert B; DZIEDZIC, Michael J \& GOLDBERG, Eliot M (eds.). Policing the New World Disorder: peace operations and public security. Washington: National Defense University Press, 1998.

PARET, Peter (ed). Makers of Modern Strategy. Princeton: Princeton University Press, 1986

PROENÇA Jr, Domício. VI 1/2: the legal and theoretical standing of PKO. Brasília: REDES 2002, 6-9 Agosto, 2002

PROENÇA Jr, Domício \& DINIZ, Eugenio. Política de Segurança no Brasil, uma análise crítica. Brasília: Editora da UnB, 1998.

PROENÇA Jr, Domício \& DINIZ, Eugenio. Segurança e of Estudos Estratégicos. In: BRIGAGÃO, Clóvis. A Estratégia das Negociações Internacionais. Rio de Janeiro: Aeroplano, 1998, p 145-202.

PROENÇA Jr, Domício \& DINIZ, Eugenio (2002). Uma apresentação à Teoria da Guerra (título provisório). Apresentação para a nova Edição de Carl von Clausewitz. Da Guerra. No prelo.

PROENÇA Jr, Domício; MUNIZ, Jacqueline \& DINIZ, Eugenio. Uma visão sistêmica dos Estudos Estratégicos. Documento de Discussão. Rio de Janeiro: Grupo de Estudos Estratégicos, 1996.

PROENÇA Jr, Domício; DINIZ, Eugenio \& RAZA, Salvador Ghelfi. Guia de Estudos de Estratégia. Rio de Janeiro: Jorge Zahar Editor, 1999.

RIKHYE, Indar Jit. The Use of Force in International Conflict Resolution. In: MORRISON, Alex; FRASER, Douglas F and KIRAS, James. (eds.). Peacekeeping with muscle: the use of force in international conflict resolution. Clemensport: Canadian Peacekeeping Press, 1997, p. 17-24.

RODRIGUEZ, Matt. Appendix A: Remarks by Chicago Police superintendent Matt Rodriguez. In: OAKLEY, Robert B; DZIEDZIC, Michael J \& GOLDBERG, Eliot M (eds.). Policing the New World Disorder: peace operations and public security. Washington, National Defense University Press, 1998, p. 537-546.

SCHMIDL, Erwin A. Speak Softly and Carry a Big Stick: the use of force in peacekeeping operations. In: MORRISON, Alex; FRASER, Douglas F and KIRAS, James. (eds.). Peacekeeping with muscle: the use of force in international conflict resolution. Clemensport: Canadian Peacekeeping Press, 1997, p. 83-90. 
SCHMIDL, Erwin A. Police Functions in Peace Operations. In: OAKLEY, Robert B; DZIEDZIC, Michael J \& GOLDBERG, Eliot M (eds.). Policing the New World Disorder: peace operations and public security. Washington: National Defense University Press, 1998, p. 19-40.

SHARP, Walter Gary, Sr. (ed.) UN Peace Operations: a collection of primary documents and readings governing the conduct of multilateral peace operations. New York: American Heritage/ Custom Publishing Group. 1995.

SHUSTA, Robert M, et al. Multicultural Law Enforcement: strategies for peacekeeping in a Diverse Society. Upper Saddle River: Prentice Hall, 1995

TRIPODI, Paolo. Peacekeeping : Let the Conscripts Do the Job. Security Dialogue. 32 (2), p. 155168, 2001.

WIDER PEACEKEEPING. The British Army Stablishment. Disponível em <http:// www.army.mil.uk>. 1994.

WISEMAN, Henry. Force: goals and consequences. In: MORRISON, Alex; FRASER, Douglas F \& KIRAS, James (eds.). Peacekeeping with muscle: the use of force in international conflict resolution. Clemensport: Canadian Peacekeeping Press, 1997, p. 177-186.

Resumo

A clareza original do que sejam as operações de manutenção, ou Missões de Paz - PKO - já não existe, se é que algum dia ela de fato existiu. No decorrer desse artigo Busca-se enquadrar as PKO nas teorias de guerra e de polícia, com base no entendimento sobre força e violência, uso da força, guerra e paz. Ao final, há algumas observações sobre a utilidade desses enquadramentos.

\section{Abstract}

The original meaning of what are the Peacekeeping Operations - PKO no longer exists, that is, if some day it really existed. This article tries to fit the PKO in the theories of war and police, based on the comprehension of strength and violence, the use of strength, war, and peace. In conclusion, there are some observations about the utility of those allocations.

Palavras-chave: Operações de Paz; ONU. Key words: Peacekeeping Operations; UN. 